\title{
Article \\ Strategies for Selecting Early Maturing Maize Inbred Lines for Hybrid Production under Low Soil Nitrogen and Striga Infestation
}

\author{
Gloria B. Adu ${ }^{1,2}$, Baffour Badu-Apraku ${ }^{3, *}$ and Richard Akromah ${ }^{2}$ \\ 1 Council for Scientific and Industrial Research (CSIR), Savanna Agricultural Research Institute, P.O. Box TL 52, \\ Tamale 00233, Ghana; gloriaboakyewaa@yahoo.com \\ 2 Department of Crop and Soil Sciences, Faculty of Agriculture, Kwame Nkrumah University of Science and \\ Technology, P.O. Box 152, Kumasi AK-039-5028, Ghana; rakromah@yahoo.com \\ 3 Maize Improvement Program, International Institute of Tropical Agriculture (IITA), PMB 5320, \\ Ibadan 200001, Oyo State, Nigeria \\ * Correspondence: b.badu-apraku@cgiar.org; Tel.: +234-810-848-2590
}

Citation: Adu, G.B.; Badu-Apraku,

B.; Akromah, R. Strategies for

Selecting Early Maturing Maize

Inbred Lines for Hybrid Production under Low Soil Nitrogen and Striga Infestation. Agronomy 2021, 11, 1309 https://doi.org/10.3390/agronomy 11071309

Academic Editor: Marcelo Carena

Received: 13 May 2021

Accepted: 25 June 2021

Published: 27 June 2021

Publisher's Note: MDPI stays neutral with regard to jurisdictional claims in published maps and institutional affiliations.

Copyright: (c) 2021 by the authors. Licensee MDPI, Basel, Switzerland. This article is an open access article distributed under the terms and conditions of the Creative Commons Attribution (CC BY) license (https:// creativecommons.org/licenses/by/ $4.0 /)$.

\begin{abstract}
Development, testing and selection of superior inbred lines is crucial for the success of a hybrid program targeting Striga-infested and low soil nitrogen (low-N) environments. The practical value of inbred lines is determined by multiple traits, most of which are inter-dependent. The main objective of this study was to identify early maturing inbred lines based on multiple traits under optimal, low-N and Striga-infested environments for hybrid development and population improvement. One hundred early maturing inbred lines were evaluated under artificial Striga-infestation, low-N and optimal growing environments for two years at Kwadaso and Nyankpala in Ghana. The inbred lines exhibited high levels of genetic variability for grain yield and other agronomic traits desirable for Striga resistance and low-N tolerance. Under optimal growing conditions, days to silking (DS), ears per plot (EHARV) and days to anthesis (DA) had high direct effects on grain yield (GYLD). Days to silking and ears per plant (EPP) had the highest positive direct effects on GYLD, while DA had the highest negative direct effect on grain yield in low-N environments. Under Striga-infestation, the highest negative direct effect on GYLD was obtained with EASP. All the measured traits previously identified to have direct influence on grain yield were associated with it and could be used for indirect selection for improved grain yield under the contrasting environments. Forty-eight of the 100 inbred lines studied were identified as low-N tolerant and forty-nine as Striga resistant.
\end{abstract}

Keywords: inbred line development; grain yield; Striga hermonthica; low soil nitrogen; secondary traits and indirect selection

\section{Introduction}

Maize (Zea mays L.) is the third most widely planted crop in the world after rice and wheat and the second most traded cereal after wheat [1]. Globally, growth in production of maize is about $2.2 \%$ per annum, mainly through harvested area increase of $0.9 \%$ per annum and global average yield increase of $1.5 \%$ per annum [2]. In sub-Saharan Africa (SSA), maize is an important staple crop for human consumption and provides at least 30 percent of the food calories for more than $50 \%$ of the population. Thus, its availability and affordability have been central to food security [3] of countries in the sub-region [4]. It is projected that if maize yield in SSA could be increased from the current $20 \%$ to $80 \%$ of the potential yield, then, SSA would attain self-sufficiency in 2050 [5,6]. Yield improvement in SSA is determined largely by the limited access of small-scale farmers to yield-enhancing inputs, such as improved seeds, fertilizers, machinery, and irrigation technologies [7]. Even where improved varieties are available, the adoption has been poor due to the failure of new varieties to address farmers' preferences or needs and their growing conditions [8]. Often improved varieties are selected for high yield under optimal agronomic conditions. 
However, when grown by farmers in marginal production areas, they have failed to provide significant advantage over the farmers' varieties and have not been adopted [9].

Yield potential is location and year specific and highly controlled by temperature, solar radiation, water, nutrient supply, pest and diseases [10]. Therefore, differences between yield potential and actual farm yield of a cultivar can only be achieved if the environmental factors are perfectly managed to enhance genetic potential of the cultivar. The three key production constraints responsible for yield reduction in SSA are soil nutrient constraints (44\%), weeds (19\%) including Striga sp., and drought (18\%) [11]. Low soil nitrogen (low-N) stress alone is estimated to cause yield losses as high as $10-50 \%$ in SSA [12,13]. The problem of poor soil fertility, particularly low-N, could be alleviated by the addition of inorganic fertilizer as commonly done in high input agricultural systems in developed countries. However, fertilizer supply is limited and the cost is prohibitive for SSA farmers [14]. As a result of high fertilizer costs, application rates in SSA are the lowest in the world [15]. The high cost of fertilizer calls for the need to maximize nitrogen use efficiency (NUE) of maize varieties [16] and encourage the use of nitrogen use efficient varieties, along with modest fertilizer use and other integrated soil fertility management practices to stabilize yields and increase the productivity of maize in SSA. Striga hermonthica (Del.) Benth is an obligate parasitic weed commonly found in cereals in the savannas of West Africa and in the mid altitudes of East Africa. It causes yield losses of between $20-100 \%$ in maize $[2,17]$. Striga control methods commonly used in SSA include hand weeding, host plant resistance; chemical control and intercropping with catch or trap crops. The use of host plant resistance, i.e., maize varieties with the genes controlling the expression of the parasitic weed germination and development is considered the most preferred control method because it is sustainable, affordable and more environmentally friendly for resource poor farmers [18,19]. The integration of Striga resistant maize varieties into Striga management programs offers the most effective and sustainable control measure for the parasitic weed [20]. Low soil fertility is also closely associated with Striga hermonthica infestation [21]. The simultaneous effects of Striga and low-N can cause yield losses up to $100 \%$ [22]. Maize production in SSA takes place mainly in rainfed systems. Maize yield is highly correlated with rainfall, which is important because drought is a defining feature of rainfed production environment. About $40 \%$ of Africa's maize-growing area faces occasional drought stress, resulting in yield losses of $10-25 \%$. About $25 \%$ of maize crop suffers from frequent drought, with losses of up to half the harvest [23,24]. Drought stress also hinders nutrient uptake. Maize grain yield is reduced by up to $80 \%$ under combined drought and low-N conditions $[25,26]$. Although the effects of uncertain and highly variable rainfall can be mitigated through the use of irrigation, SSA has the lowest level of irrigation development in the world. Only $4 \%$ of agricultural land in SSA is irrigated. As the effect of climate change advances and maize production continues to expand into marginal production areas, the effects of drought, Striga and low-N stresses will remain major challenges in places where most farmers have limited capacity to invest in inputs [27].

The savanna agro-ecologies of Ghana, representing the northern part of the country, have the greatest potential for increased maize production because solar radiation is high and incidence of pests and diseases is very low in these zones. However, maize productivity in northern Ghana is greatly constrained by drought, low soil fertility and Striga infestation $[7,28,29]$. Under field conditions, there are also often complex interactions among these stresses with more devastating effects on the yield of maize [30,31]. Investment in maize research is required to produce a new generation of improved multiple-stress tolerant varieties that are drought tolerant, Striga resistant and nutrient use efficient in Ghana and Africa as a whole. The adoption of stress tolerant maize could generate USD 362 to USD 590 million within the maize production and consumption sector, which can seriously reduce poverty by $5 \%$ in SSA [32].

Substantial progress in breeding for stress tolerant maize for African farmers has been achieved. Since 1990, the International Maize and Wheat Improvement Center 
(CIMMYT) and the International Institute of Tropical Agriculture (IITA) together with their global network of partners have developed several maize varieties (including breeding populations, open-pollinated varieties, hybrids and inbred lines) and relevant breeding techniques aimed at addressing major production constraints in Africa. These include drought, low-N and acid soil conditions, Striga and insects [33,34]. The present study is part of broader research that focused on the utilization of new inbred lines developed by the West and Central Africa Collaborative Maize Research Network/International Institute of Tropical Agriculture (WECAMAN/IITA), for development of locally adapted maize hybrids with multiple-stress tolerance/resistance to Striga and low-N for the savanna zones of Ghana, in particular and West and Central Africa (WCA), in general. The selected inbred lines included 100 early maturing white and yellow lines developed for drought/low-N and Striga tolerance. Before hybrid development, there is a need to have adequate knowledge of the level of genetic diversity within the selected inbred lines for grain yield and other Striga and low-N adaptive traits as well as the breeding value of the inbred lines to guide the selection of prospective parents of the desired hybrids. Since the majority of the inbred lines selected for this study are newly developed, there is little to no information on them with regards to these important genetic parameters, which would facilitate their use in hybrid development. To address these research gaps, a series of experiments were conducted to determine the genetic diversity, heterotic grouping, combining ability and heterosis for grain yield and other agronomic traits of the inbred lines under Striga infestation, low-N and optimal growing conditions. The present study assessed the agronomic performance and trait associations of the inbred lines under optimal conditions, Striga-infested and low-N environments to aid identification of superior lines through the use of multiple-trait selection index.

Genetic variation for stress adaptive traits is expressed differently at optimal and marginal environments. Thus, genes for adaptation to marginal environments can only be observed when genotype evaluation is conducted under sufficiently stressed conditions [7,35-38]. The indirect selection of genotypes in optimal environments for performance in other contrasting environments is usually complicated by the presence of genotype by environment interaction (GEI). The presence of biotic (Striga) and/or abiotic (Low-N and drought) stresses compound the GEI effects, probably due to the complexities in the genetics of resistance/tolerance of genotypes to stresses [39]. Genotype by environment interaction due to the relative differences in the response of genotypes to contrasting environments reduces the correlation between phenotypic and genotypic values [40] under stress environments. In maize, the relative effect of GEI on a genotype vary from one trait to the other with pronounced effects on quantitatively inherited traits such as grain yield. Most research outputs by CIMMYT have shown that variety selection based on grain yield alone under drought and low-N environments are usually inefficient because heritability of grain yield under stressed environments is low [4]. Under such conditions, the use of secondary traits have improved selection efficiency in maize [41]. According to Edmeades et al. [41] an ideal secondary trait should be: genetically associated with grain yield under stress; highly heritable; genetically variable; cheap and fast to measure; stable within the measurement period, not associated with a yield penalty under non-stressed conditions observed at or before flowering, so that undesirable parents are not crossed and are reliable estimators of yield potential before final harvest [35]. Traditionally, a selection index based on increased grain yield, reduced barrenness, reduced anthesis-silking interval (ASI), delayed leaf senescence, good plant and ear aspects is used to select for high yielding genotypes with tolerance to low-N and drought [42-44]. For Striga resistance improvement programs, a selection index which combines increased grain yield measured under Striga-infested and Striga-free environments, reduced Striga damage, reduced number of emerged Striga plants, good ear aspect and increased number of ears per plant (EPP) is used [7,45]. The use of these selection indices has been very successful in the past $[7,46]$. However, recent studies involving the same selection indices have reported inconsistent results. For instance, contrary to reports by Menkir and Akintunde [43] and Badu-Apraku and Oyekunle [47], 
results of Badu-Apraku et al. [48] indicated that the stay green characteristic is not a reliable trait for selecting genotypes that are drought tolerant, while EPP and ASI are also unreliable characters for identifying low-N tolerant genotypes. The authors identified plant height, days to silking, and days to anthesis, which are not included in the low-N selection index as reliable for selecting early maturing inbred lines under low-N conditions. Reports by Badu-Apraku et al. [48] and Badu-Apraku and Fakorede [7] indicated that the number of emerged Striga plants, which have a strong association with grain yield in late and intermediate maturity group of maize $[7,45]$, have a weak phenotypic and genotypic correlations with grain yield in the early maturity group. Badu-Apraku and Fakorede [7] found that after four cycles of $S_{1}$ family selection in an extra-early maturing population under Striga infestation, grain yield was not correlated with other traits at $\mathrm{C}_{0}$ but was significantly correlated with EPP, Striga damage and the number of emerged Striga plants in advanced cycles. A review of these contradictory results showed a trend dependent on the type of germplasm under selection, the kind of trait and the level of improvement already achieved in the desired germplasm. Since there is the possibility for every set of breeding lines to have unique trait associations, validation of long established secondary traits and assessment of the possible use of other traits in the selection of high yield and stress tolerant genotypes is relevant in breeding programs [46]. The main objective of this study was to identify superior early maturing maize inbred lines that can contribute useful traits for hybrid development for stable production in low-N and Striga infested environments, and also to be used for population improvement. The specific objectives of this study were to assess the relationship between grain yield and secondary traits of 100 white and yellow early maturing inbred lines, and also to assess the agronomic performance of the selected set of early maturing inbred lines based on multiple traits under optimal conditions, Striga-infested and low-N environments.

\section{Materials and Methods}

\subsection{Genetic Materials}

The 100 inbred lines used in this study were bred by the West and Central Africa Collaborative Maize Research Network/International Institute of Tropical Agriculture (WECAMAN/IITA) (Table S1). They are resistant/tolerant to Striga and maize streak virus (MSV) and/or tolerant to drought. The inbred lines were extracted from twelve broadbased and two narrow-based source populations developed from both local and exotic germplasm identified based on several years of extensive testing for adaptation to the Guinea and Sudan savanna agro-ecologies of West and Central Africa. The first generation of inbred lines were obtained following six generations of self-pollination in four early (TZE-W Pop DT STR C 0 , TZE-Y Pop DT STR $C_{0}$, TZE Comp5-Y $C_{6}$ and WEC STR) and two extra-early (TZEE-W Pop DT STR $\mathrm{C}_{0}$ and TZEE-Y Pop DT STR $\mathrm{C}_{0}$ ) broad-based populations with varied levels of drought tolerance and Striga resistance. A few inbred lines extracted from the two extra-early source populations were categorized as early maturing because the flowering dates were typical of lines of the early maturing group. A second generation of inbred lines were developed from two $\mathrm{F}_{2}$ populations derived from the bi-parental crosses, TZEI $1 \times$ TZEI 2 and TZEI $11 \times$ TZEI 8, which involved elite parental inbred lines from two of the four broad-based early maturing populations. Another set of inbred lines were extracted from two other bi-parental crosses, TZE-W Pop $\times 1368$ STR and TZE-W Pop $\times$ LD. The second generation of inbred lines were in all cases obtained following 6-7 cycles of self-pollination and selection for drought tolerance and/or resistance to Striga.

\subsection{Field Evaluations}

The inbred lines were evaluated in three different experiments in 2014 and 2015. In the first experiment, the inbred lines were evaluated for agronomic performance under artificial Striga infestation at Nyankpala $\left(9^{\circ} 25^{\prime} \mathrm{N}\right.$ and $0^{\circ} 58^{\prime} \mathrm{E}, 340 \mathrm{~m}$ ASL, $800 \mathrm{~mm}$ annual rainfall) in the Guinea savanna zone of Ghana. A $10 \times 10$ square lattice design with two replications were used. The experimental units were one-row plots, each $3 \mathrm{~m}$ long 
with an inter-row spacing of $0.75 \mathrm{~m}$ and intra-row spacing of $0.40 \mathrm{~m}$. Each entry was infested with seeds of Striga hermonthica. About 5000 germinable Striga seeds were used in each hill for infestation. The Striga infestation method of the IITA maize program was used [49]. To promote germination and attachment of Striga to the roots of host plants under Striga infestation, fertilizer application was delayed until about 21 days after planting (DAP) [31,49] when $30 \mathrm{~kg} \mathrm{~N} \mathrm{ha}^{-1}, 30 \mathrm{~kg} \mathrm{P} \mathrm{ha}^{-1}$ and $30 \mathrm{~kg} \mathrm{~K} \mathrm{ha}^{-1}$ was applied as 15-15-15 NPK. Weeds other than Striga were controlled manually.

In the second experiment, the inbred lines were evaluated under low- $\mathrm{N}\left(30 \mathrm{~kg} \mathrm{~N} \mathrm{ha}^{-1}\right)$ environment at Kwadaso $\left(6^{\circ} 42^{\prime} 0^{\prime \prime} \mathrm{N}\right.$ and $1^{\circ} 39^{\prime} 0^{\prime \prime} \mathrm{W}, 251 \mathrm{~m}$ ASL, $1500 \mathrm{~mm}$ annual rainfall) in the Forest zone of Ghana. The experimental field used for the low-N evaluations had already been depleted of $\mathrm{N}$ by continuously planting maize and removing the biomass after each harvest for several seasons. Soil analyses were conducted using the Kjeldahl digestion and colorimetric method [50]. Based on the results of the soil test (Table 1), fertilizer was applied to bring the total available $\mathrm{N}$ to $30 \mathrm{~kg} \mathrm{ha}^{-1}$ for low-N environments. The $\mathrm{N}$ fertilizer was applied at $2 \mathrm{WAP}$, immediately after thinning. Single superphosphate $\left(\mathrm{P}_{2} \mathrm{O}_{5}\right)$ and muriate of potash $\left(\mathrm{K}_{2} \mathrm{O}\right)$ were applied to the low-N plots at the rate of $60 \mathrm{~kg} \mathrm{ha}^{-1}$ as well. The experiments were kept weed free with the application of atrazine (1-chloro3-ethylamino-5-isopropylamino-2-4-6-triazine) as pre-emergence herbicide at $5 \mathrm{~L} \mathrm{ha}^{-1}$ and subsequently by hand weeding when necessary.

The inbred lines were also evaluated under optimal growing conditions, high-N (90 kg N ha ${ }^{-1}$ ) and Striga-free environments in the third experiment at Nyankpala and Kwadaso. The experimental design and plot size were similar to that used in the first and second experiments. A compound fertilizer was applied at the rate of $60 \mathrm{~kg} \mathrm{ha}^{-1} \mathrm{~N}, \mathrm{P}$ and $\mathrm{K}$ at $2 \mathrm{WAP}$ immediately after thinning. An additional $30 \mathrm{~kg} \mathrm{~N}^{-1}$ was top-dressed 4 weeks later. Weed control method used in the third experiment were the same as those used in the second experiment.

Table 1. Initial soil properties of experimental field used for the low-N experiments at Kwadaso in Ghana.

\begin{tabular}{ccccc}
\hline \multirow{2}{*}{ Soil Properties } & \multicolumn{2}{c}{ Soil Depth } & \multicolumn{2}{c}{ Interpretation } \\
\cline { 2 - 5 } & $\mathbf{0 - 1 5} \mathbf{~ c m}$ & $\mathbf{1 5 - 3 0 ~} \mathbf{~ m}$ & High & Low \\
\hline $\mathrm{pH}(1: 1)$ & 7.38 & 6.98 & $>6.5$ & $<5.8$ \\
Organic C (\%) & 1.32 & 0.58 & $>10.0$ & $<4.0$ \\
Total N (\%) & 0.16 & 0.10 & $>0.5$ & $<0.2$ \\
Ex Ca $(\mathrm{Cmolc} / \mathrm{kg})$ & 6.00 & 3.94 & $>10.0$ & $<4.0$ \\
Ex Mg $(\mathrm{Cmolc} / \mathrm{kg})$ & 5.18 & 3.10 & $>4.0$ & $<0.5$ \\
Ex K (Cmolc/kg) & 0.25 & 0.20 & $>0.6$ & $<0.2$ \\
Ex Na $(\mathrm{Cmolc} / \mathrm{kg})$ & 0.21 & 0.20 & $>1.0$ & $<1.0$ \\
$\mathrm{Av} \mathrm{P}(\mathrm{Mg} / \mathrm{kg})$ & 35.82 & 12.13 & $>50.0$ & $<15.0$ \\
\hline
\end{tabular}

Ex: Exchangeable, Av: Available.

\subsection{Data Collection}

Data were recorded on low-N, optimal and Striga-infested as described by Abe et al. [51] and [31,49] for days to anthesis (DA), days to silking (DYSK), anthesis-silking interval, ear height (EH), plant height (PHT), plant aspect (PASP), ear aspect (EASP), root lodging (RL) and ears per plant (EPP). Ear aspect (EASP) was based on a scale of 1-9, where 1 = clean, uniform, large and well-filled ears and $9=$ ears with undesirable features Plant aspect (PASP) was recorded on a scale of 1 to 9 based on overall plant type, where $1=$ excellent plant type and $9=$ poor plant type. Grain yield was adjusted to $15 \%$ moisture and computed from the shelled grain weight, while grain yield was calculated based on field weight in the Striga-infested and optimal experiments. A shelling percentage of $80 \%$ was assumed for inbred lines per plot and grain yield (obtained from ear weight and converted to $\mathrm{kg} \mathrm{ha}^{-1}$ ) was adjusted to $15 \%$ moisture content. In addition to these traits, stay green characteristic (SGR), Striga emergence counts (STRCO) at 8 and 10 WAP and 
Striga damage syndrome rating (STRRAT) at 8 and $10 \mathrm{WAP}$ were measured following the procedure of $[31,44]$.

\subsection{Data Analysis}

\subsubsection{Analysis of Variance}

Separate analyses of variance (ANOVA) were performed on all collected data under optimal, low-N and Striga infested environments using the general linear model procedure (PROC GLM) in the statistical analysis system (SAS) [52], using a random statement with test option. Striga emergence counts were transformed using natural logarithm transformation (LN (count +1$)$ ) before analysis. Subsequently, combined ANOVA across locations and years were performed for DA, DS, EASP, EH, PHT, PS, PHARV, EHARV, ER, HC, PASP, RL, SL, GYLD, ASI and EPP. Each combination of location by year was regarded as a test environment. In the combined ANOVA, the environments, replicates within environment, incomplete blocks within replicates $\times$ environment interaction were regarded as random factors. The entries were considered as fixed factors.

\subsubsection{Multiple Trait Selection Index for Low-N Tolerance and Striga Resistance}

The IITA maize program's base index for identifying genotypes with low-N tolerance [43] and Striga resistant/tolerant [53] genotypes were used. The selection indices described below were used to characterize and separately select inbred lines with tolerance and/or resistance to Striga and low-N environments. The base index used for selection of Striga resistance/tolerance $\left(\mathrm{BI}_{\mathrm{STR}}\right)$ was computed as follows:

$$
\mathrm{BI}_{\text {STR }}=[(2 \times \text { GYLD })+\mathrm{EPP}-(\text { STRRAT1 }+ \text { STRRAT2 })-0.5(\mathrm{STRCO} 1+\mathrm{STRCO} 2)]
$$

where GYLD was the mean grain yield of Striga-infested plots, EPP is the number of ears per plant in Striga-infested plots, STRRAT1 and STRRAT2 were Striga damage syndrome rating at 8 and $10 \mathrm{WAP}$, respectively and STRCO1 and STRCO2 were the number of emerged Striga plants at 8 and $10 \mathrm{WAP}$, respectively. The base index for selection for low-N tolerant inbred lines $\left(\mathrm{BI}_{\mathrm{LN}}\right)$ was computed as follows:

$$
\mathrm{BI}_{\mathrm{LN}}=[(2 \times \mathrm{GYLD})+\mathrm{EPP}-\mathrm{ASI}-\mathrm{PASP}-\mathrm{EASP}-\mathrm{SGR}]
$$

where GYLD was the mean grain yield of low-N plots, PASP was the plant aspect, EASP was the ear aspect, EPP was the number of ears per plant, ASI was the anthesis-silking interval and SGR was the stay green characteristic. A base index for multiple stress tolerance (MI) proposed by Badu-Apraku et al. [46] was used to select inbred lines with multiple stress tolerance to low-N and Striga infestation. The multiple stress tolerance base index was computed as follows:

$\mathrm{MI}=(2 \times \mathrm{GYLD})+\mathrm{EPP}-\mathrm{EASP}-\mathrm{PASP}-\mathrm{SGR}-\mathrm{STRRAT1}-\mathrm{STRRAT2}-(0.5 \times \mathrm{STRCO} 1)-(0.5 \times \mathrm{STRCO} 2)$

where GYLD was the grain yield, EPP was the number of ears per plant, EASP was the ear aspect and PASP was the plant aspect across Striga infestation, low-N and stressfree environments; SGR was the stay green characteristic under low-N environment; STRRAT1 and STRRAT2, and STRCO1 and STRCO2 were the Striga damage at 8 and 10 WAP and number of emerged Striga plants at 8 and 10 WAP across Striga-infested environments. Under Striga infestation, low-N and optimal growing conditions, each trait was standardized, with a mean of zero and standard deviation of 1 to minimize the effects of different scales. For each test environment, therefore, a positive value indicated tolerance while a negative value indicated susceptibility of the inbred line to the respective stresses. For selection across environments, a positive MI value was considered an indication of combined tolerance/resistance to low-N and Striga infestation, while negative values indicated susceptibility. 


\subsubsection{Path Coefficient Analysis of Grain Yield and Yield Components}

The entry means of measured traits under each of the three research conditions (optimal, Striga-infested and low-N environments) were standardized and used for phenotypic correlation and multiple regression analyses in Microsoft office Excel (2013 version). In the multiple regression analysis, traits that caused high multicollinearity effects were removed step by step from the analysis. Outputs from the correlation and regression analyses were used for path coefficient analysis following procedures described by Akintunde [54] to calculate the direct and indirect effects of the other traits on grain yield.

\subsubsection{Genotype by Trait and Trait Association by Environment Analyses}

The GGE biplot pattern explorer [55] was used for trait association and trait profile analyses. The model for genotype by trait (GT) biplot [56] used is presented below:

$$
\frac{\left(Y_{i j}-\mu-\beta_{j}\right)}{d_{j}}=\lambda_{1} g_{i 1} e_{1 j}+\lambda_{2} g_{i 2} e_{2 j}+\varepsilon_{i j}
$$

where $Y_{i j}$ is the genetic value of the combination between inbred $i$ and trait $j ; \mu$ is the mean of all combinations involving trait $j ; \beta_{j}$ is the main effect of trait $j ; \lambda_{1}$ and $\lambda_{2}$ are the singular values for PC1 and PC2; $g_{i 1}$ and $g_{i 2}$ are the PC1 and PC2 eigenvectors, respectively, for inbred $i ; e_{1 j}$ and $e_{2 j}$ are the PC1 and PC2 eigenvectors, respectively, for trait $j: d_{j}$ is the phenotypic standard deviation (with mean of zero and standard deviation of 1); and $\varepsilon_{i j}$ is the residual of the model associated with the combination of inbred $i$ and trait $j$. The data were not transformed ('Transform $=0^{\prime}$ ), but were standard deviation-standardized ('Scale $=1$ '), and trait-centered ('centering $=2$ '). Therefore, the outputs are appropriate for visualizing the relationships among genotypes and traits.

Trait association by environment (ABE) biplot analysis $[57,58]$ was used to display associations between grain yield as a target trait and days to anthesis, days to silking, plant height, ears per plant, ear aspect, and plants and ears harvested per plot as explanatory traits. The analysis was based on procedures by Yan and Tinker [57]. The "multi-trait decision maker-against toplines" module, which combines independent selection and culling, and index selection in one selection platform was used to identify lines adapted to all the three research conditions. It was specified that an inbred line having a level lower than $70 \%$ of the top inbred line for any trait should be discarded ("independent culling"), and a genotype with a level higher than $95 \%$ of the best inbred line for any trait should be retained ("independent selection"). Independent selection takes the priority, independent culling the second, and index selection the last. The following traits and weights were used: days to silking $(-0.7)$, days to anthesis $(-0.7)$, plants per plot (0.5), ears per plot (0.7) and grain yield (1.0).

\section{Results}

3.1. Analysis of Variance of Grain Yield and Other Traits of the Early Maturing Inbred Lines under Optimal, Striga-Infested and Low-N Growing Environments, and across Test Environments

Analysis of variance across the optimal growing environments (Table 2) showed significant genotypic differences among the inbred lines for grain yield, days to anthesis and silking, ears per plant, ear aspect and plant and ear heights (Table 2). Mean square values for environment were significant for grain yield, plant height and ear height. Genotype $\times$ environment $(G \times E)$ interaction was significant for grain yield, plant aspect, days to anthesis, days to silking and ear aspect (Table 2). Results of analysis of variance showed significant $(p \leq 0.001)$ genotypic mean squares for grain yield, ears per plant, ear aspect, plant height and Striga damage syndrome ratings at eight and 10 WAP under artificial Striga infestation (Table 2). The mean squares for environment was significant $(p \leq 0.001)$ for ear height, plant height, root lodging and stalk lodging under Striga-infested environments. Significant differences $(p \leq 0.001)$ were detected among the inbred lines for grain yield, days to anthesis, days to silking, ears per plant, ear aspect, ear height and stay green 
characteristic across the low-N environments (Table 2). There were significant differences among environments for grain yield, ear height, plant height and root lodging in low-N environments. Combined ANOVA across optimal growing conditions, Striga-infested and low-N environments showed significant differences $(p \leq 0.001)$ among genotypes for days to anthesis, days to silking, plant height, ear aspect, ear height and ears per plant. Differences among environments were also significant $(p \leq 0.001)$ for grain yield, days to anthesis, days to silking, plant height, ear aspect, ear height, ears per plant, root lodging and stalk lodging (Table 3). Genotype $x$ environment interaction was highly significant for grain yield, days to anthesis, days to silking, plant height, ear aspect and ears per plant (Table 3).

\subsection{Mean Performance of the Inbred Lines under Optimal, Striga-Infested and Low-N Environments, and across Test Environments}

Averaged across test environments, overall mean grain yield of the inbred lines was $802 \mathrm{~kg} \mathrm{ha}^{-1}$ (Table S2). Mean grain yield was highest under optimal growing conditions (1121 kg ha $\left.{ }^{-1}\right)$ followed by low-N (7I7 kg ha $\left.{ }^{-1}\right)$ and lowest under Striga infestation (569 $\mathrm{kg} \mathrm{ha}^{-1}$ ) (Table S2). Under Striga infestation and low-N environments, anthesis-silking interval was higher and the number of root lodged plants was greater (Figures 1 and 2). Plant height and ears per plant of the inbred lines reduced under Striga infestation and low-N with a more pronounced reduction in plant height under low- $\mathrm{N}$. The days to silking was greater under low-N, while the ear aspect was worst under Striga infestation (Figure 2). Using the multiple-trait indices [20] for selection of Striga resistant/tolerant, low-N tolerant and multiple-stress tolerant inbred lines. forty-eight of the 100 inbred lines had positive base index values under low-N environments $(0.2$ to 17.0$)$, while forty-nine of them had positive base index values under Striga infestation (0.1 to 7.5) (Table S2).

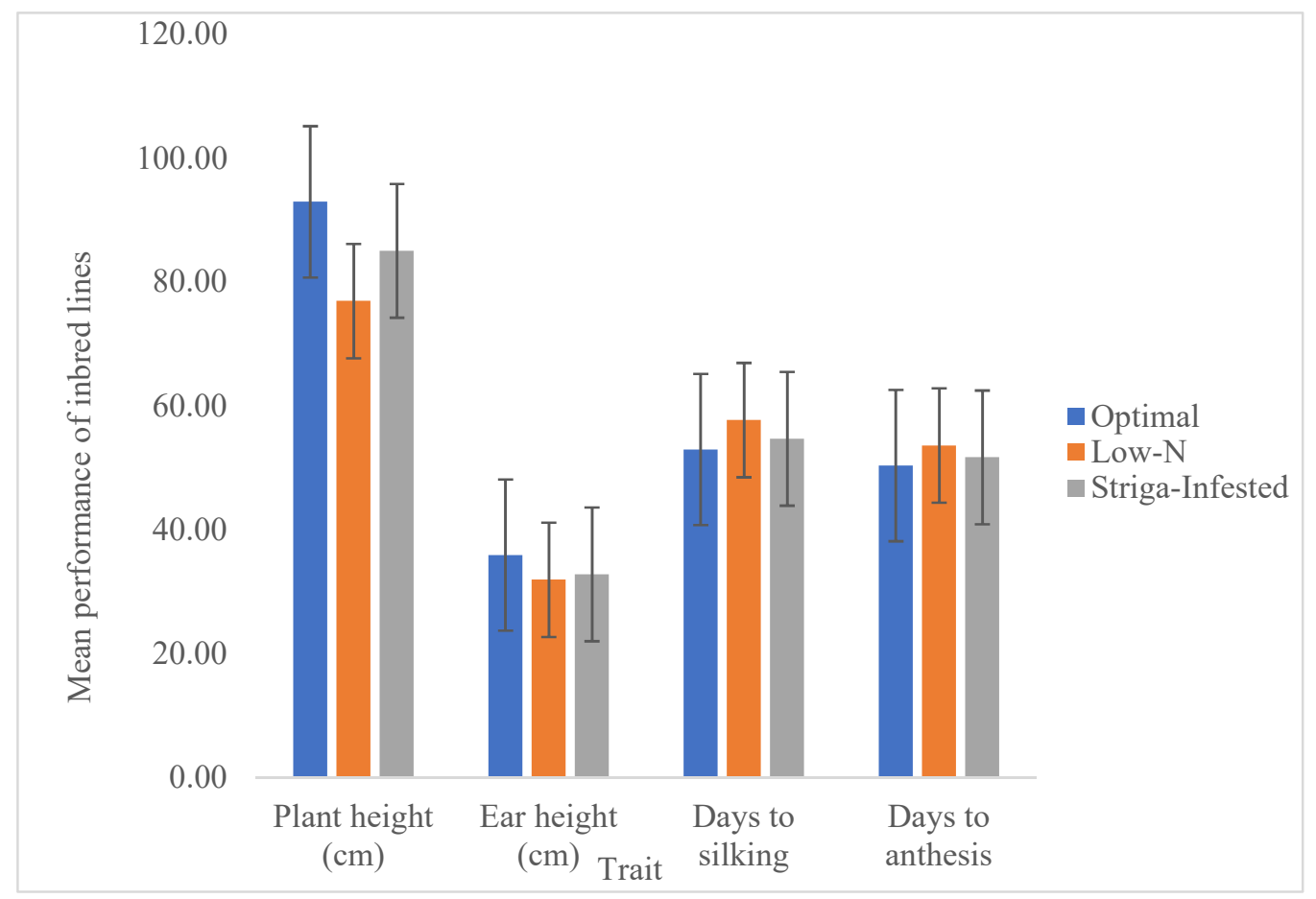

Figure 1. Mean plant height, ear height, days to silking and days to anthesis of the 100 inbred lines evaluated across optimal growing conditions, Striga-infested and low-N environments. 


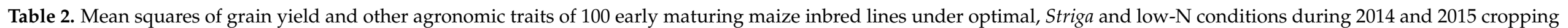
seasons at Nyankpala and Kwadaso in Ghana.

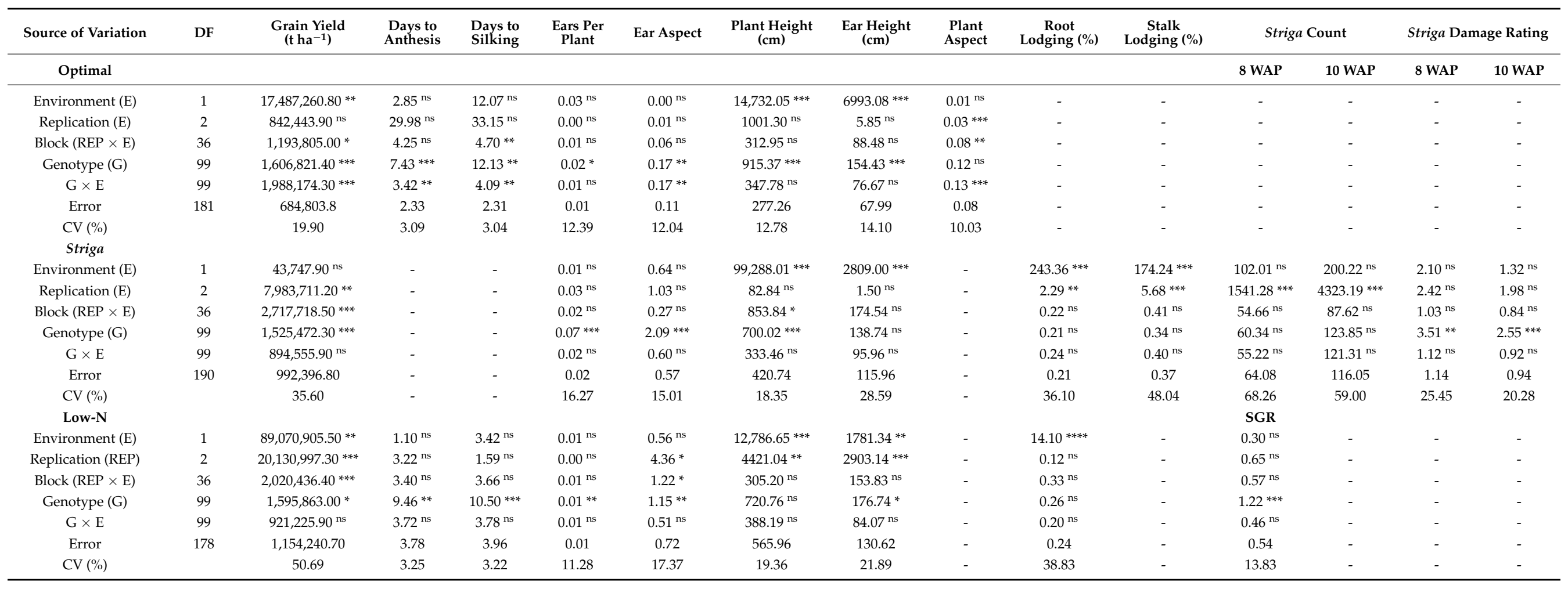

${ }^{*} p \leq 0.05,{ }^{* *} p \leq 0.01,{ }^{* * *} p \leq 0.001,{ }^{\text {ns }}=$ non-significant, respectively, REP $=$ replication; SGR = stay green characteristics. 


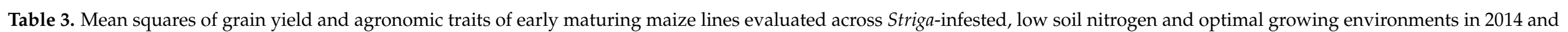
2015 at Nyankpala and Kwadaso in Ghana.

\begin{tabular}{|c|c|c|c|c|c|c|}
\hline Source of Variation & DF & Grain Yield $\left(t h^{-1}\right)$ & Days to Anthesis & Days to Silking & Plant Height $(\mathrm{cm})$ & Ear Aspect \\
\hline Environment (E) & 5 & $321,843,225.00 * * *$ & $4445.58 * * *$ & $5634.280^{* * *}$ & $38,946.90^{* * *}$ & $264.29 * * *$ \\
\hline Replication (REP) & 1 & $14,095,825.00^{* * *}$ & $14.23 *$ & $9.866^{\mathrm{ns}}$ & $590.67^{\mathrm{ns}}$ & $2.94 * *$ \\
\hline Block (Rep) & 18 & $1,981,338.00 * *$ & $5.97^{* *}$ & $7.908^{* *}$ & 742.54 * & $0.80 *$ \\
\hline $\mathrm{G} \times \mathrm{E}$ & 495 & $1,463,220.00^{* * *}$ & $6.75^{* * *}$ & $8.180 * * *$ & $395.24^{\mathrm{ns}}$ & $0.69^{* * *}$ \\
\hline Error & 578 & $1,004,312$ & 2.93 & 3.572 & 416.87 & 0.47 \\
\hline \multirow[t]{2}{*}{$\mathrm{CV}(\%)$} & & 38.91 & 3.13 & 3.388 & 16.79 & 16.21 \\
\hline & & Ear height $(\mathrm{cm})$ & Ears per plant & Root lodging (\%) & Stalk lodging (\%) & \\
\hline Environment (E) & 5 & $20,503.31^{* * *}$ & $0.56^{* * *}$ & $59.38^{* * *}$ & $69.69 * * *$ & \\
\hline Replication (E) & 6 & $989.97^{* *}$ & $0.01^{\mathrm{ns}}$ & $1.13^{\mathrm{ns}}$ & $1.39^{\mathrm{ns}}$ & \\
\hline Block $($ REP $\times$ E $)$ & 108 & $214.57^{* *}$ & $0.0^{\mathrm{ns}}$ & $0.18^{\mathrm{ns}}$ & $0.30^{\mathrm{ns}}$ & \\
\hline Genotype (G) & 99 & $229.22 * * *$ & $0.03^{* * *}$ & $0.24^{\mathrm{ns}}$ & $0.28^{\mathrm{ns}}$ & \\
\hline $\mathrm{G} \times \mathrm{E}$ & 495 & 100.09 & $0.02 * * *$ & $0.18^{\text {ns }}$ & $0.39^{\mathrm{ns}}$ & \\
\hline Error & 578 & 106.53 & 0.02 & 0.18 & 0.36 & \\
\hline CV $(\%)$ & & 20.87 & 13.28 & 40.03 & 46.12 & \\
\hline
\end{tabular}




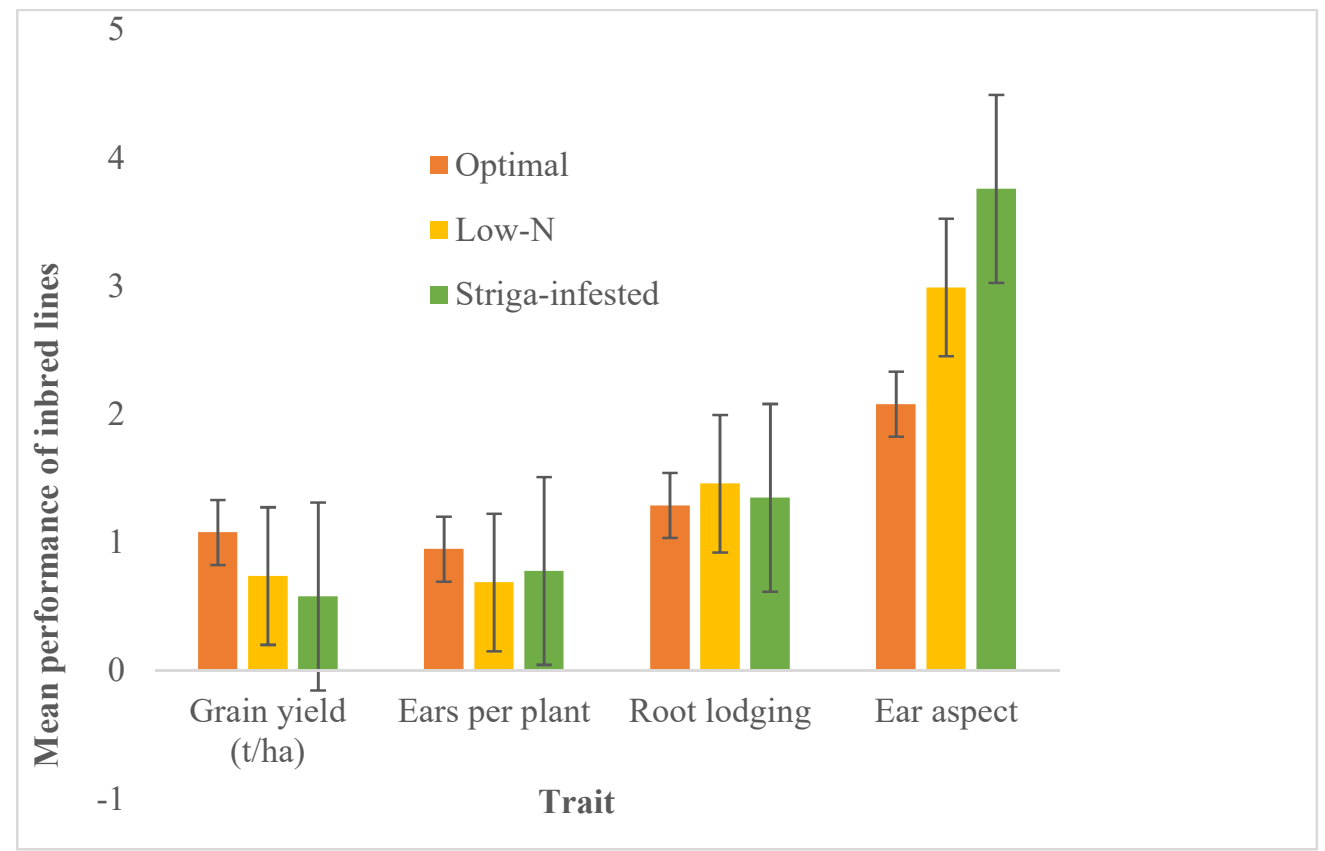

Figure 2. Mean grain yield ( $\mathrm{t} / \mathrm{ha}$ ), ears per plant, root lodging and ear aspect of the 100 inbred lines evaluated across optimal growing conditions, Striga-infested and low-N environments.

\subsection{Path Coefficient Analysis of Grain Yield and Other Traits}

The results of regression analysis revealed that the independent traits studied accounted for $47 \%, 36 \%$ and $44 \%$ of the total variation in grain yield (dependent trait) under optimal, Striga-infested, and low-N conditions, respectively (Tables 4-6). Under optimal growing conditions, plants per plot (0.48), ear aspect (0.25) and ears per plot (0.5) had the highest correlation with grain yield. Days to silking (0.78), ears per plot (0.65), days to anthesis $(-0.49)$ and anthesis-silking interval $(-0.36)$ were traits with high direct effects on grain yield (Table 4). Days to silking had an indirect effect on grain yield through days to anthesis $(-0.41)$ and ASI $(-0.19)$, while days to anthesis had an indirect effect on grain yield through days to silking (0.65). Ear aspect ( -0.51$)$, ears per plot $(0.45)$ and plants per plot (0.37) had the highest association with grain yield under artificial Striga infestation (Table 5). The highest negative direct effect on grain yield was obtained by ear aspect $(-0.66)$. Plants per plot had indirect contribution to grain yield through ears per plot $(0.27)$ and STRRAT2 $(-0.06)$. Plant height $(0.28)$, ears per plot $(-0.03)$ and days to silking $(0.04)$ had indirect effects on grain yield through ear aspect. Ear height indirectly contributed to grain yield through plant height $(-0.04)$ while days to anthesis had an indirect effect on grain yield through days to silking (0.18) (Table 5).

Under low-N environments, traits such as days to anthesis $(-0.75)$, days to silking $(-0.68)$ and ears per plant (0.64) had high associations with grain yield (Table 6). Days to silking (0.31) and ears per plant (0.44) had the highest positive direct effects on grain yield, while days to anthesis $(-0.93)$ had the highest negative direct effect on grain yield. Stay green characteristic $(-0.20)$ and ear aspect $(-0.05)$ had a lower negative indirect effect on grain yield, while plant aspect (0.00) had no direct effect on grain yield. Days to anthesis contributed indirectly to grain yield through ears per plant $(-0.08)$ and days to silking (0.29) (Table 6). 
Table 4. Path analysis of the effects of various traits on grain yield of the inbred lines under optimal growing conditions.

\begin{tabular}{|c|c|c|c|c|c|c|c|c|c|c|c|c|c|c|}
\hline \multirow{2}{*}{ Trait } & \multirow{2}{*}{$\begin{array}{l}\text { Correlation } \\
\text { Coefficient }\end{array}$} & \multirow{2}{*}{$\begin{array}{l}\text { Direct } \\
\text { Effect }\end{array}$} & \multicolumn{12}{|c|}{ Indirect Effect } \\
\hline & & & PHT & EH & ASI & SL & RL & PHARV & PASP & EHARV & EASP & EPP & DYSK & DA \\
\hline PHT & 0.04 & 0.18 & & 0.14 & -0.06 & -0.03 & 0.01 & 0.01 & 0.00 & 0.02 & -0.03 & 0.02 & -0.03 & 0.00 \\
\hline $\mathrm{EH}$ & 0.03 & -0.26 & -0.20 & & 0.10 & 0.01 & 0.00 & -0.05 & -0.03 & -0.05 & 0.05 & -0.02 & 0.02 & -0.04 \\
\hline SL & 0.04 & -0.08 & 0.01 & 0.00 & 0.00 & & -0.01 & -0.02 & -0.01 & -0.01 & 0.00 & 0.01 & 0.01 & 0.01 \\
\hline RL & -0.01 & -0.03 & 0.00 & 0.00 & 0.00 & -0.01 & & 0.00 & 0.00 & 0.00 & 0.00 & 0.00 & 0.01 & 0.01 \\
\hline PHARV & 0.48 & 0.04 & 0.00 & 0.01 & 0.00 & 0.01 & 0.00 & & 0.01 & 0.03 & -0.01 & 0.00 & 0.00 & 0.00 \\
\hline PASP & 0.12 & 0.02 & 0.00 & 0.00 & 0.00 & 0.00 & 0.00 & 0.00 & & 0.00 & -0.01 & 0.00 & 0.00 & 0.00 \\
\hline EHARV & 0.50 & 0.65 & 0.08 & 0.13 & -0.07 & 0.08 & 0.04 & 0.47 & 0.13 & & -0.16 & 0.37 & -0.05 & -0.01 \\
\hline EASP & -0.25 & -0.14 & 0.02 & 0.03 & 0.01 & 0.01 & 0.00 & 0.02 & 0.04 & 0.03 & & 0.02 & 0.01 & 0.00 \\
\hline EPP & 0.11 & -0.29 & -0.03 & -0.03 & 0.02 & 0.05 & 0.01 & 0.01 & -0.04 & -0.16 & 0.04 & & 0.00 & -0.01 \\
\hline DYSK & 0.16 & 0.78 & -0.12 & -0.07 & 0.42 & -0.07 & -0.14 & -0.03 & -0.03 & -0.06 & -0.04 & -0.01 & & 0.65 \\
\hline DA & 0.13 & -0.49 & -0.01 & -0.08 & 0.01 & 0.05 & 0.09 & -0.01 & 0.01 & 0.01 & 0.00 & -0.01 & -0.41 & \\
\hline \multicolumn{15}{|c|}{ Regression Statistics } \\
\hline $\mathrm{R}^{2}$ & & 0.47 & & & & & & & & & & & & \\
\hline Standard Error & & 0.84 & & & & & & & & & & & & \\
\hline Observations (n) & & 100 & & & & & & & & & & & & \\
\hline
\end{tabular}

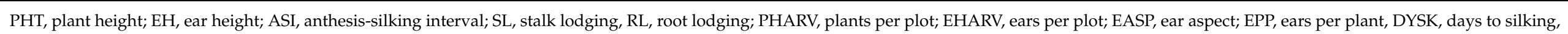
DA, days to anthesis.

Table 5. Path analysis of effects of various traits on grain yield of the inbred lines under artificial Striga infestation.

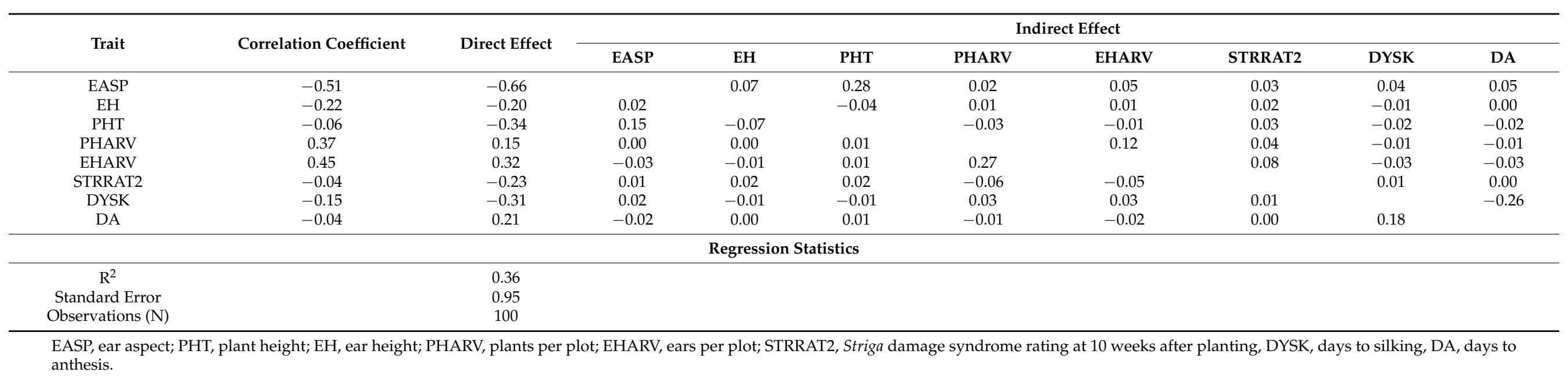


Table 6. Path analysis of the effects of various traits on grain yield of the inbred lines under low soil nitrogen environment.

\begin{tabular}{|c|c|c|c|c|c|c|c|c|c|c|c|}
\hline \multirow{2}{*}{ Trait } & \multirow{2}{*}{$\begin{array}{l}\text { Correlation } \\
\text { Coefficient }\end{array}$} & \multirow{2}{*}{ Direct Effect } & \multicolumn{9}{|c|}{ Indirect Effect } \\
\hline & & & EPP & DYSK & DA & PASP & EASP & SGR & PHT & EH & RL \\
\hline EPP & 0.64 & 0.44 & & -0.10 & -0.08 & -0.09 & -0.04 & -0.12 & 0.00 & 0.07 & -0.02 \\
\hline DYSK & -0.68 & 0.31 & -0.07 & & 0.29 & 0.05 & 0.01 & 0.03 & 0.03 & -0.05 & 0.02 \\
\hline DA & -0.75 & -0.93 & 0.17 & -0.87 & & -0.16 & -0.04 & -0.09 & -0.09 & 0.17 & -0.05 \\
\hline PASP & -0.32 & 0.00 & 0.00 & 0.00 & 0.00 & & 0.00 & 0.00 & 0.00 & 0.00 & 0.00 \\
\hline EASP & -0.13 & -0.05 & 0.00 & 0.00 & 0.00 & -0.01 & & 0.00 & 0.00 & 0.00 & 0.00 \\
\hline SGR & -0.42 & -0.20 & 0.06 & -0.02 & -0.02 & -0.06 & -0.01 & & 0.01 & 0.01 & 0.02 \\
\hline PHT & 0.16 & 0.13 & 0.00 & 0.01 & 0.01 & -0.01 & 0.01 & 0.00 & & 0.04 & 0.00 \\
\hline RL & -0.05 & -0.02 & 0.02 & 0.02 & 0.02 & -0.01 & -0.01 & -0.02 & 0.00 & 0.00 & \\
\hline \multicolumn{12}{|c|}{ Regression Statistics } \\
\hline $\mathrm{R}^{2}$ & & 0.44 & & & & & & & & & \\
\hline Standard Error & & 0.78 & & & & & & & & & \\
\hline Observations (n) & & 100 & & & & & & & & & \\
\hline
\end{tabular}

EPP, ears per plant, DYSK, days to silking, DA, days to anthesis; EASP, ear aspect; SGR, stay green characteristic; PHT, plant height; EH, ear height; RL, root lodging. 


\subsection{Genotype by Trait (GT) and Trait Association by Environment (ABE) Analyses}

The biplots presented in Figures $3-5$ explained $59.8 \%, 72.1 \%$ and $56.22 \%$ of the total variation of the environment-centered $\mathrm{G} \times \mathrm{E}$ of the multi-trait data of the inbred lines under optimal, low-N and Striga-infested environments, respectively. They were therefore appropriate for visualizing the associations among traits in the respective environments. The lines that connect the traits to the biplot origin are called tester (trait) vectors. The correlation between the traits is approximated by cosine of the angle between their vectors. The biplot in Figure 3 presented the trait association among grain yield and other traits under optimal growing conditions. The biplot showed a close acute angle between DS and DA; between PHT and GYLD, and between PHARV and EHARV, indicating a strong positive correlation between each pair of traits under optimal growing conditions. The angle between the following traits was also acute: GYLD and EPP, GYLD and EHARV, GYLD and PHARV, DS and PHT, and DA and PHT, showing that these traits were positively correlated. On the contrary, the angles between EASP and EPP, and EASP and GYLD were obtuse, indicating negative correlation between them. The inbred line TZEI 344 was the vertex inbred line where PHT, DA and DS fell. The inbred line TZEI 124 was the vertex inbred line where GYLD, EPP, EHARV and PHARV fell. The inbred line TZdEI 222 was the vertex inbred line for EASP (Figure 3).

The biplot in Figure 4 showed a close acute angle between DS and DA, PHT and EHARV, PHARV and EHARV, and GYLD and PHT under low-N environments. This indicated a close positive correlation between each pair of traits. The angle between EASP and DS and DA as well as between GYLD and PHARV were acute but wide, indicating a weak positive correlation among these traits. There was an obtuse angle between DA and GYLD, PHT, PHARV and EHARV, but the obtuse angle between DA and GYLD and PHT was the widest. This indicated very strong negative correlation between DA and GYLD and PHT. The inbred line TZdEI 92 was the vertex inbred line where DA and DS fell, while EASP fell where TZEI 5 was. TZEI 35 was the vertex inbred line where GYLD, PHT, EHARV and PHARV fell (Figure 4).

Under Striga-infested environments, GYLD had an acute angle with EHARV, PHARV and STRRAT2 but an obtuse angle with PHT, DS and EASP (Figure 5). This showed positive association between GYLD and EHARV, PHARV and STRRAT2, and negative association between GYLD and PHT, DS and EASP. The EASP had an acute angle with DS and a wide obtuse angle with GYLD. TZEI 124 was the vertex inbred line for PHT. TZdEI 51 was the vertex inbred line for GYLD, EHARV and PHARV. The inbred lines TZEI 467 was the vertex inbred line for STRRAT2, while the vertex inbred line for EASP and DS was TZdEI 84 (Figure 5). The association by environment (ABE) biplot in Figure 6 explained $99.5 \%$ of the variation of the total sum of squares in the multi-trait data on the inbred lines across optimal, low-N and Striga-infested environments. The biplot revealed that DS, DA, EHARV and PHARV are explanatory traits with the highest influence on GYLD across the test environments, except for low-N environment in 2014. The most outstanding inbred lines across research environments were TZEI 56, TZdEI 283, TZEI 18, TZEI 31, TZEI 35, TZEI 379, TZEI 476, TZEI 124, and TZEI 13. 


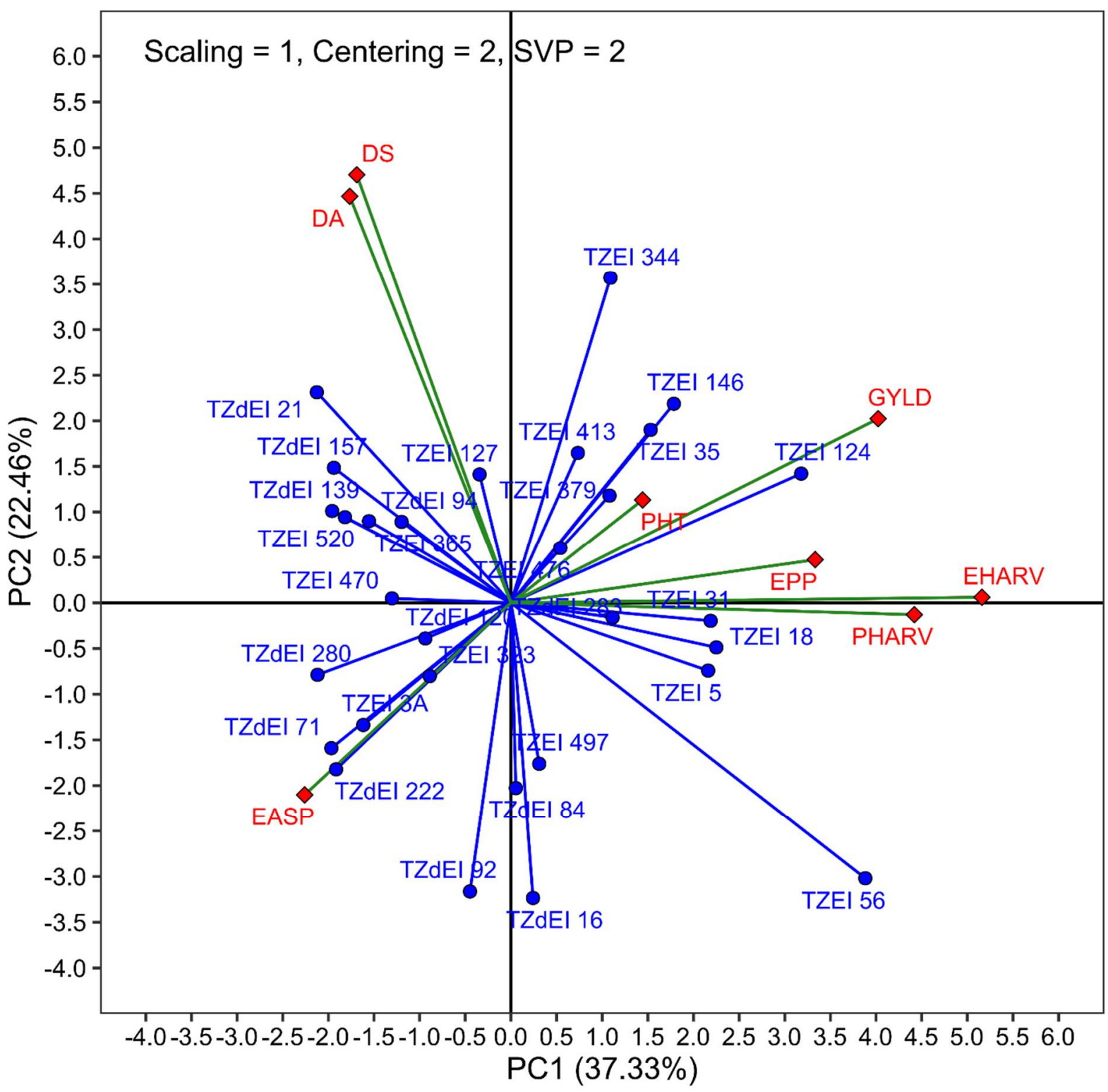

Figure 3. Genotype by trait biplot based on multi-trait data of the top 15 and bottom 15 grain yielding inbred lines evaluated at Kwadaso and Nyankpala in 2015 under optimal growing conditions. + DS, days to silking; DA, days to anthesis; PHT, plant height; GYLD, grain yield; EPP, ears per plant; EHARV, ears per plot; PHARV, plants per plot; EASP, and ear aspect. 


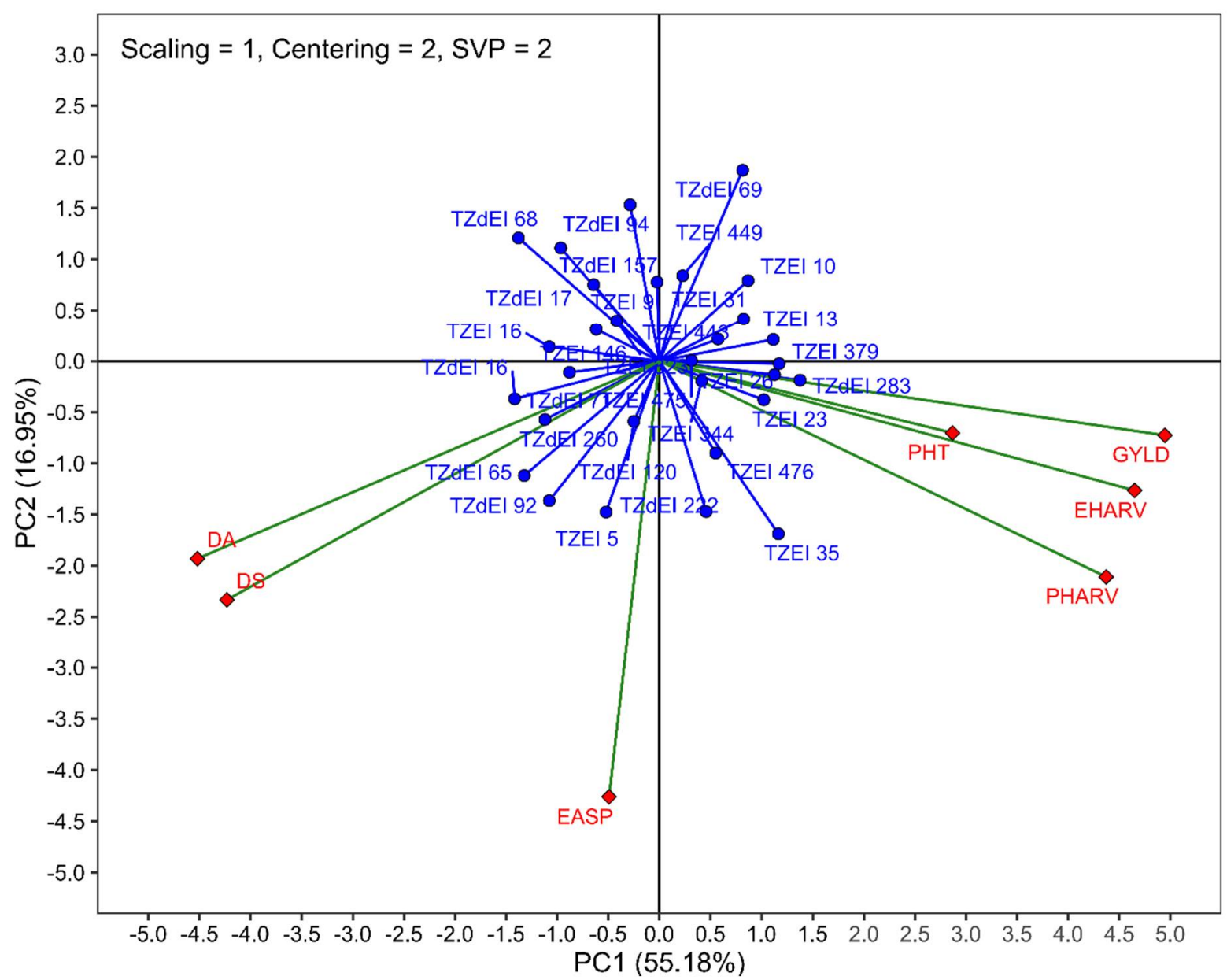

Figure 4. Genotype by trait biplot based on multi-trait data of the top 15 and bottom 15 grain yielding inbred lines evaluated at Kwadaso in 2014 and 2015 under low-N environments. + DS, days to silking; DA, days to anthesis; PHT, plant height; GYLD, grain yield; EHARV, ears per plot; PHARV, plants per plot; EASP, ear aspect. 


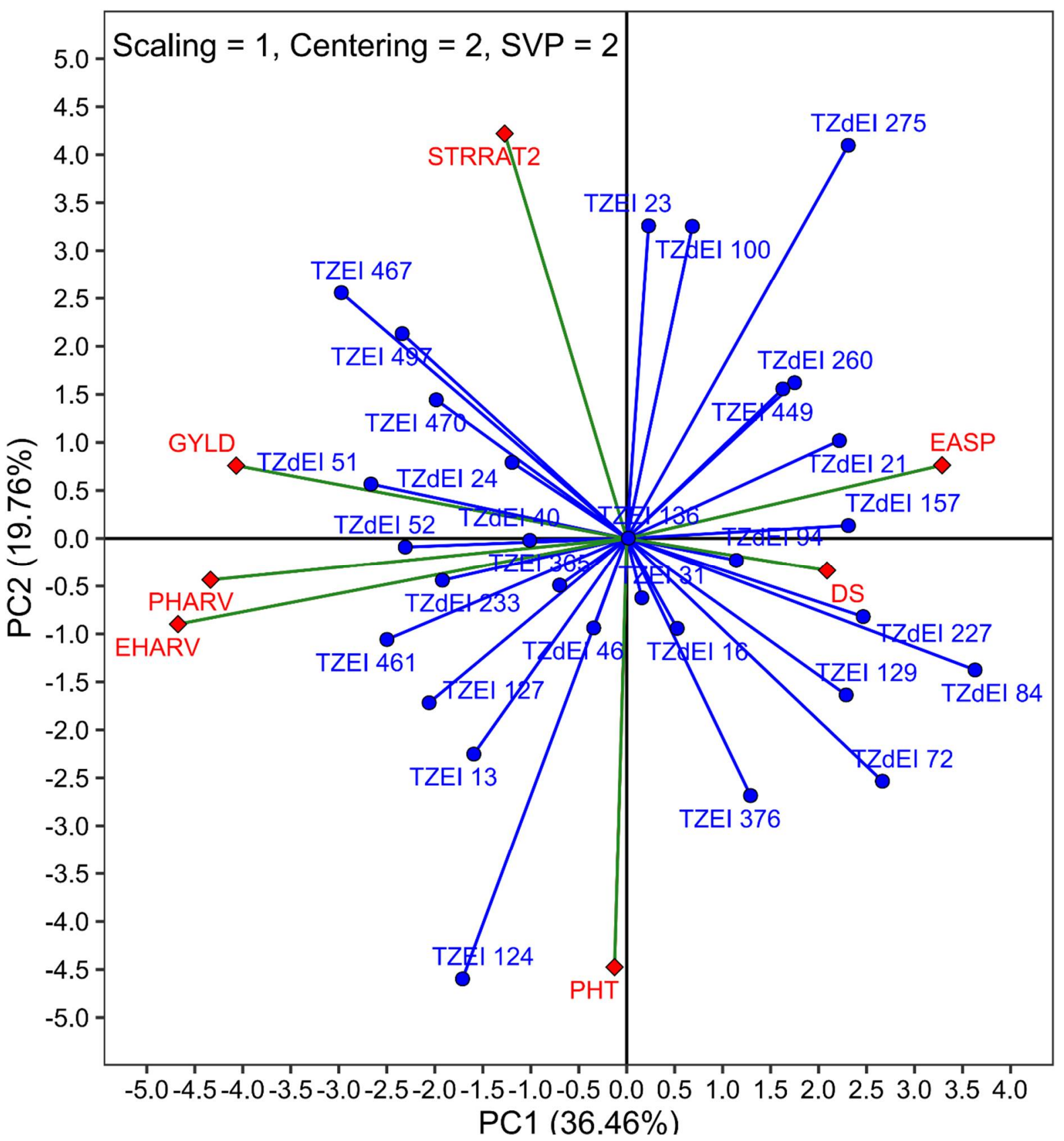

Figure 5. Genotype by trait biplot based on multi-trait data of the top 15 and bottom 15 grain yielding inbred lines evaluated at Nyankpala in 2014 and 2015 under artificial Striga infestation. + DS, days to silking; PHT, plant height; GYLD, grain yield; EHARV, ears per plot; PHARV, plants per plot; EASP, ear aspect; STRRAT2. 


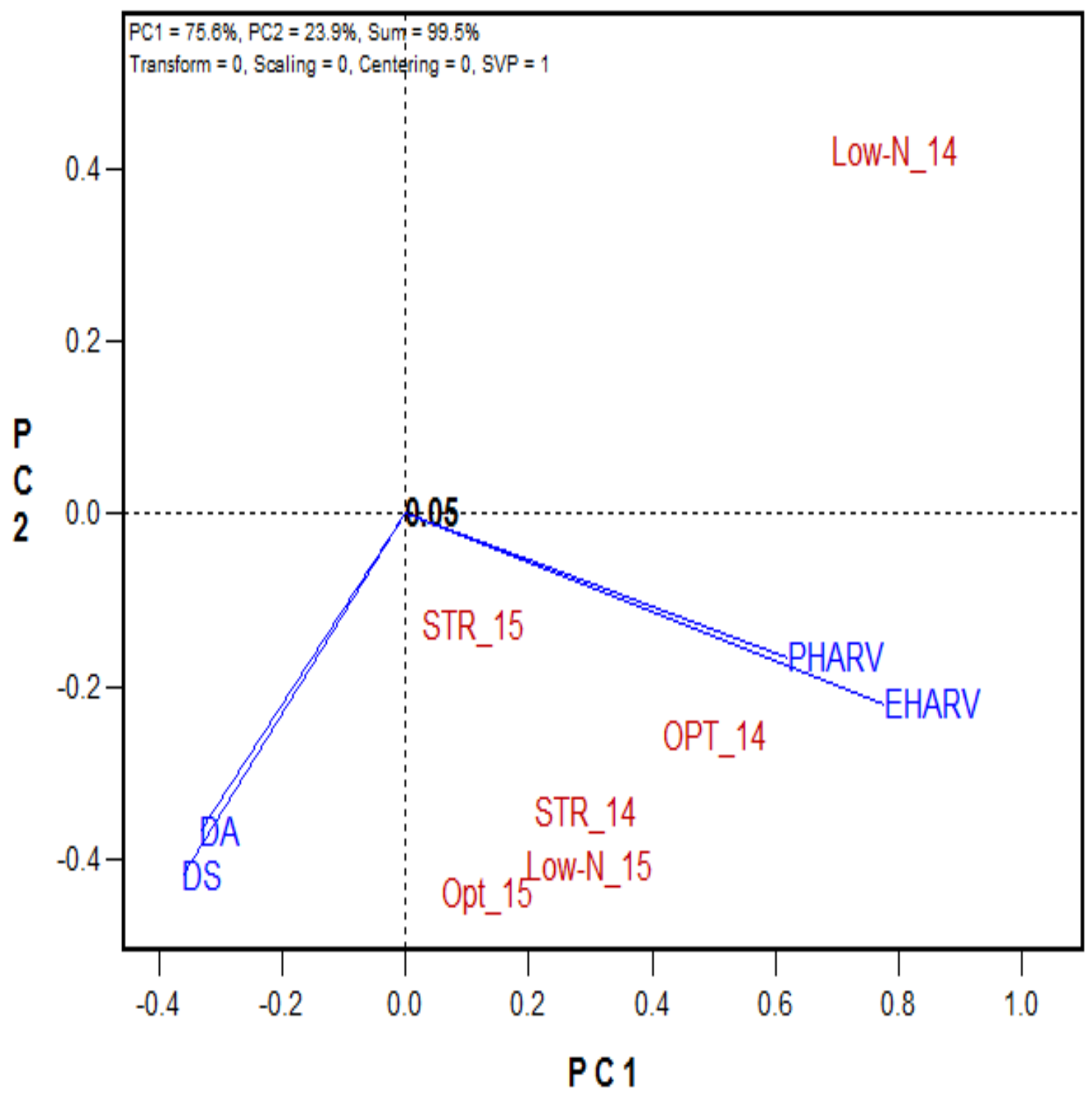

TYPE-\| ABE biplot

Figure 6. Trait association by environment biplot showing the correlations of days to anthesis, days to silking, plants and ears per plot with grain yield across the six test environments in 2014 and 2015. + DS, days to silking; DA, days to anthesis; EHARV, ears per plot; PHARV, plants per plot.

\section{Discussion}

The observed significant genotypic, environment and GEI mean squares for most measured traits under Striga infestation, low-N and optimal growing environments indicated that the test environments were unique and diverse, and provided important information on the inbred lines. It also indicated that there was adequate genetic variability among the inbred lines to allow for significant progress to be made in selection for Striga resistance and low-N tolerance. Thus, there are potential parental lines for productive hybrid development for the targeted environments. Similar findings were reported by Badu-Apraku et al. [59,60] and Akaogu et al. [61]. The significant interaction between genotype and environment for grain yield, days to anthesis and silking, plant height, ear aspect and ears per plant across the six test environments indicated that the expression of these traits will be inconsistent across environments and years. Therefore, the inbred lines should be evaluated under the different study environments across years to identify Striga 
tolerant/resistant and/or low-N tolerant inbred lines with consistently favorable response to either one or both stresses [60-64].

Nitrogen is the most important nutrient for the growth of maize, thus, the lack of it restricts plant growth, development and eventual yield. Based on the results of this study, traits, such as plant height, grain yield, ear aspect, days to silking and ears per plant, which were the most limited by nitrogen deficiency must be carefully considered when selecting low-N tolerant early maturing inbred lines. Several authors have reported similar effects of nitrogen stress on grain yield and its component traits [65-67]. The observed delay in silking together with wide anthesis-silking interval under low-N might have induced barrenness, thus contributing to $36 \%$ grain yield reduction under low- $\mathrm{N}$. The maize ear has a relatively weak sink capacity at flowering as a result; a reduction in nitrogen availability during flowering can reduce the flux of assimilates to the ear. This results in delay in silking, an increase in anthesis-silking interval, kernel abortion, barren plants and ultimately reduced grain yield $[65,66]$.

Striga infestation significantly reduced grain yield and almost all yield components studied. On average, yield performance, ear aspect and ears per plant suffered a severe reduction of $49 \%, 26 \%$ and $21 \%$, respectively under Striga infestation relative to being under optimal conditions. This result suggested that ear aspect and ears per plant were key traits to consider when selecting early maturing Striga resistant inbred lines for improved yield under Striga-infested conditions. These results corroborated the findings of Adetimirin et al. [68] whereby studies involving early maturing inbred lines and hybrids revealed that pre-flowering stress due to Striga parasitism was higher than post-flowering stress and thus resulted in higher reduction of ears per plant $(44 \%)$ than reductions for other yield components $(12 \pm 29 \%)$. The performance of the inbred lines with respect to key Striga adaptive traits, such as Striga damage syndrome rating and number of emerged Striga plants, was outstanding. Generally, the inbred lines supported considerably fewer numbers of emerged Striga plants of 9 and 21 plants per plot, respectively, at 8 and 10 WAP. The number of emerged Striga plants recorded in this study are below the range of 21-31 Striga plants at 8 WAP and 24-39 emerged Striga plants at 10 WAP reported by $[39,47,69]$. The fewer number of emerged Striga plants recorded in this study might have been influenced by the large number of test inbred lines with Striga resistance genes derived from the germplasm with Zea diploperennis genetic background. According to Lane et al. [70], genotypes with genes from Zea diploperennis restrict the penetration of its roots by Striga plants and impair the development and survival of Striga parasites. The selection index used to select superior inbred lines under Striga-infested environment revealed that $49 \%$ of the inbred lines used in the present study might have possessed some level of tolerance and/or resistance to Striga. They possessed desirable alleles for resistance to Striga, which could have been used to develop more stable Striga resistant hybrids and used also as sources of Striga resistant alleles for population improvement.

Grain yield is a quantitative trait and is functionally related to yield components, particularly when evaluated under stress. Breeder's knowledge of the degree of association among grain yield and its component traits is crucial, given that the selection of certain traits influences the behavior of other traits in crops [46]. The results of the path analyses revealed that days to silking, ears per plot, days to anthesis and anthesis-silking interval had the highest direct effects on grain yield under optimal conditions, while ear aspect, plant height, days to silking, STRRAT2 and ears per plant were the traits with the greatest direct influence on grain yield under Striga infestation. Under low-N, days to silking, ears per plant and days to anthesis were the most important traits with direct effects on grain yield. The results indicated that these traits could be used for indirect selection for improved grain yield in the respective environments. It is important to note that plant aspect, which is used in the IITA base index for selecting low-N tolerant early genotypes [62,71], did not have direct effect on grain yield. Furthermore, stay green characteristic considered as a key secondary trait in the identification of low-N tolerant genotypes [35] had much weaker association with grain yield in the present study. The results of the present study 
were similar to the results of another study by Badu-Apraku et al. [44], which revealed low correlation between the stay green characteristic and grain yield of extra-early inbred lines under both drought stress and low-N environments. Overall, the results of this study suggested that days to silking, ears per plant and plant height are more reliable traits for simultaneous selection of low-N tolerant early maturing inbred lines than stay green characteristic and plant aspect.

The path analysis also revealed that the direct and indirect effects of some of the measured traits on grain yield changed in magnitude and were inconsistent in direction across environments. The direct effect of days to anthesis on grain yield was moderately weak (0.49) under optimal conditions but approached 0.93 under low-N. The direct effect of ears per plant on grain yield also increased from -0.29 to 0.44 under optimal and low-N environments, respectively. Moreover, the indirect effect of days to silking on grain yield through days to anthesis and ears per plant also increased under low-N. These results are consistent with reports by Bänziger et al. [35] who reported that correlation between grain yield and other yield components becomes stronger under stress. These results also showed a strong dependence of grain yield on flowering traits and hence, corroborated the findings of $[35,39]$ on the effects of nitrogen deficiency on flowering, pollination and ear-setting processes of maize, and their consequent effects on yield of genotypes under nitrogen deficient environments. The positive correlation of days to anthesis and days to silking with grain yield under optimal growing conditions, the positive indirect effect of days to anthesis on yield through days to silking under optimal and low-N environments, as well as the positive direct effects of days to anthesis on grain yield under Striga infestation, suggested that generally the inbred lines that matured late performed better than those that matured early in all the test environments. Sharifi and Namvar [72] also found that yield potential of maize increased with increased days to anthesis and silking. Plant and ear heights usually have a positive association with grain yield in maize, therefore, the observed negative direct and indirect effects of plant and ear heights on grain yield under Striga infestation is noteworthy. Theoretically, shorter plants have a lower amount of vegetative biomass, which reduces resource-use per plant for vegetative growth and maintenance, resulting in greater resource availability for grain production [72].

The trait associations revealed by the genotype by trait biplots are consistent with the main patterns of trait associations revealed by the path coefficient analyses under optimal conditions, low-N and Striga-infested environments. The results of the genotype by trait biplots showed that high yielding inbred lines in optimal growing conditions tended to be taller, had higher number of ears per plant and number of ears per plot as well as longer days to anthesis and silking. On the other hand, inbred lines with low grain yield had contrasting trait profile. In an earlier study involving extra-early maturing hybrids by Adu et al. [73], higher grain yield was associated with increased plant height, number of plants and ears per plot as well as good ear aspect under optimal conditions. The inbred lines TZEI 124 and TZEI 344 possessed two or more of the desirable traits above and might have displayed the best performance under optimal conditions. Under low-N environments, high yielding inbred lines had taller plants and higher number of ears per plot. They were also earlier maturing. This result indicated that plant height, days to anthesis and ears per plot were invaluable traits in the selection for high grain yield under low-N environments. This result is consistent with the findings of Badu-Apraku et al. [69]. Using genotype-by-trait biplot analyses, the authors [69] found plant height and ear aspect as dependable traits for indirect selection for high yielding genotypes in nitrogen deficient and moisture-stressed environments. Under low-N, TZEI 35 had the best yield performance, were taller, and had the highest number of plants and ears harvested per plot. It could be invaluable resource in low-N breeding programs.

The pattern of associations among the traits identified under artificial Striga infestation indicated that high yielding inbred lines in Striga-infested environments had higher number of ears and plants per plot, shorter plants and were earlier maturing. High yielding inbred lines also had the lowest Striga damage syndrome ratings at $10 \mathrm{WAP}$ and best ear aspect. 
Poor yielding inbred lines had contrasting characteristics compared to those of the higher yielding lines. The strong association between grain yield and ear aspect indicated that it could be used to select for high yielding inbred lines in Striga infested environments without sacrificing information on the inbred lines. The inbred line TZdEI 51 was identified as the best genotype for grain yield while TZEI 124 had the highest plant height and TZdEI 84 had the worst ear aspect and longest days to silking. The ABE biplot analysis identified days to anthesis, days to silking, plant height and number of ears harvested per plot as the most important traits with the greatest influence on grain yield of the inbred lines across optimal, low-N and Striga-infested environments. Using these four traits and grain yield in the multi-trait selection index, TZEI 56, TZdEI 283, TZEI 18, TZEI 31, TZEI 35, TZEI 379, TZEI 476, TZEI 124 and TZEI 13 were identified as the most adapted inbred lines across the test environments. They may therefore be the most suitable parents for production of hybrids with improved grain yield across the three research environments. Generally, the promising inbred lines identified for each of the test environments could be the best choice of parental lines for developing hybrids with maximum expression of tolerance to low-N and Striga infestation. However, since the per se performance of inbred lines is not a good indicator of the performance of the resulting hybrids, especially for grain yield [74], there is the need to evaluate the inbred lines in hybrid combinations under the target environments to identify those with high combining abilities and better hybrid responses in the target environments.

A major objective of the present study was to identify early maturing maize inbred lines based on multiple traits under optimal, low-N and Striga-infested environments for hybrid development and population improvement. The high levels of genetic variability exhibited by the inbred lines for grain yield and other agronomic traits desirable for Striga resistance and low- $\mathrm{N}$ tolerance suggested that they would be useful in the development of superior high yielding hybrids as well as for population improvement.

\section{Conclusions}

The relative performance of the inbred lines in grain yield and other agronomic traits were altered by Striga parasitism and low-N stresses in the present study. The grain yield of the inbred lines was reduced by $36 \%$ and $49 \%$ under low-N and Striga-infested environments, respectively, when compared to their yield under optimal growing conditions. Under Striga-infested environments, high grain yield was associated with good ear aspect, shorter plants, greater number of ears per plot and a lowest Striga damage syndrome rating at 10 WAP. High yielding inbred lines in low-N environments had prolonged days to silking and anthesis, more ears per plant, taller plants and good ear aspect, whereas inbred lines with high grain yield across optimal, Striga-infested and low-N environments had taller plants, shorter days to silking and anthesis, larger number of plants and ears per plot. The inbred lines TZEI 56, TZdEI 283, TZEI 18, TZEI 31, TZEI 35, TZEI 379, TZEI 476, TZEI 124 and TZEI 13 identified as the most adapted across the optimal, low-N and Striga-infested environments, are recommended as potential parents for production of high yielding hybrids, as well as for population improvement.

Supplementary Materials: The following are available online at https://www.mdpi.com/article/10 .3390 /agronomy11071309/s1, Table S1: List of inbred lines used in the study and their respective endosperm colour and pedigree information, Table S2: Grain yield and multiple-trait base index value of the 100 inbred lines evaluated under optimal growing conditions, Striga-infested and low-N environments at Nyankpala and Kwadaso in Ghana.

Author Contributions: Conceptualization, G.B.A., B.B.-A. and R.A.; Methodology, G.B.A., B.B.-A. and R.A.; Software and Formal analysis, G.B.A. and R.A.; Investigation, G.B.A., B.B.-A. and R.A.; Resources, B.B.-A. and G.B.A.; Data curation, G.B.A. and B.B.-A.; Writing-original draft preparation, G.B.A. and B.B.-A.; Writing-review and editing, B.B.-A., G.B.A. and R.A.; Supervision, B.B.-A. and R.A.; Project administration, B.B.-A.; Funding acquisition, B.B.-A. and G.B.A. All authors have read and agreed to the published version of the manuscript. 
Funding: This work was funded by the Bill \& Melinda Gates Foundation and the Alliance for a Green Revolution in Africa (AGRA).

Institutional Review Board Statement: Not applicable.

Informed Consent Statement: Not applicable.

Data Availability Statement: The datasets generated during the present study are available from the lead and corresponding authors on request.

Acknowledgments: The authors are thankful for the financial support from the Bill \& Melinda Gates Foundation [OPP1134248] through the Drought Tolerant Maize for Africa (DTMA) project in IITA. We are also grateful for funding support from AGRA (2013 PASS 028). The authors wish to express their profound appreciation for the field assistance of the staff of the Maize Improvement programs of CSIR-Savanna Agricultural Research Institute, Tamale, Ghana, IITA, Ibadan and CSIR-Crops Research Institute, Kwadaso, Ghana.

Conflicts of Interest: The authors declare no conflict of interest.

\section{References}

1. FAO; STAT. FAOSTAT Online Database. 2014. Available online: http://faostat3.fao.org/faostat-gateway/go/to/browse/G1/*/E (accessed on 1 September 2019).

2. Fischer, R.A.; Byerlee, D.; Edmeades, G.O. Crop Yields and Global Food Security: Will Yield Increase Continue to Feed the World? Canberra: Australian Centre for International Agricultural Research. 2014. Available online: http://aciar.gov.au/publication/ mn158 (accessed on 20 January 2019).

3. Badu-Apraku, B.; Fakorede, M.A.B. Advances in Genetic Enhancement of Early and Extra-Early Maize for Sub-Saharan Africa; Springer International Publishing: Berlin/Heidelberg, Germany, 2017. [CrossRef]

4. CGIAR. Research for Maize. Why Maize. 2016. Available online: http:/ / maize.org/why-maize (accessed on 2 October 2017).

5. $\quad$ van Ittersum, M.K.; van Bussel, L.G.J.; Wolf, J.; Grassini, P.; van Wart, J.; Guilpart, N.; Claessens, L.; de Groot, H.; Wiebe, K.; Mason-D'Croz, D.; et al. Can sub-Saharan Africa feed itself? Proc. Natl. Acad. Sci. USA 2016, 113, 14964-14969. [CrossRef]

6. FAO; STAT. Global Area under Cultivation and Output of Maize. 2013. Available online: http://faostat3.fao.org/download/Q/ QC/E (accessed on 1 September 2019).

7. Banziger, M.; de Meyer, J. Collaborative maize cultivar development for stress-prone environments in Southern Africa. In Farmers, Scientist and Plant Breeding; Cleveland, D.A., Solaria, D., Eds.; CAB International: Wallingford, UK, 2002; pp. $269-296$.

8. Banzinger, M.; Diallo, A.O. Progress in developing drought and N stress tolerant maize cultivars for eastern and southern Africa. In Proceedings of the Seventh Eastern and Southern Africa Regional Maize Conference, Nairobi, Kenya, 5-11 February 2002.

9. Cleveland, D.A.; Soleri, D. Farmers, Scientists and Plant Breeding: Integrating Knowledge and Practice; CABI Publishing: New York, NY, USA, 2002; pp. 239-289.

10. van Wart, J.; van Bussel, L.G.; Wolf, J.; Licker, R.; Grassini, P.; Nelson, A.; Boogaard, H.; Gerber, J.; Mueller, N.D.; Claessens, L.; et al. Use of agro-climatic zones to upscale simulated crop yield potential. Field Crop. Res. 2013, 143, 44-55. [CrossRef]

11. Gibbon, D.; Dixon, J.; Flores Velazquez, D. Beyond Drought Tolerant Maize: Study of Additional Priorities in Maize. 2007. Available online: http:/ / repository.cimmyt.org/xmlui/handle/10883/818?locale-attribute=en (accessed on 2 October 2017).

12. Wolfe, D.W.; Henderson, D.W.; Hsiao, T.C.; Alvio, A. Inter- active water and nitrogen effects on maize. II. Photosyn- thetic decline and longevity of individual leaves. Agron. J. 1988, 80, 865-870. [CrossRef]

13. Logrono, M.L.; Lothrop, J.E. Impact of drought and low nitrogen on maize production in Asia. In Developing Drought- and Low N-Tolerant Maize, Proceedings of a Symposium, 25-29 March 1996; Edmeades, G.O., Ed.; CIMMYT: El Batan, Mexico, 1997; pp. 39-43.

14. Mosier, A.R.; Syers, J.K.; Freney, J.R. Global assessment of nitrogen fertilizer: The SCOPE/IGBP nitrogen fertilizer rapid assessment project. Sci. China Ser. C Life Sci. 2005, 48, 759-766.

15. Kidane, W.; Maetz, M.; Dardel, P. Food Security and Agricultural Development in Sub Saharan Africa; FAO: Rome, Italy, 2006.

16. Wong, M.T.F.; Nortcliff, S. Amelioration of Soil Acidity in Tropical Soils with Agroforestry Residues. In Third Conference on Forest Soils (ISSS-AISS-IBG); Schulte, A., Ruhiyat, D., Eds.; Mulawarman University Press: Samarinda, Indonesia, 1995 ; pp. 60-71.

17. Mohamed, K.I.; Musselman, L.J.; Riches, C.R. The genus Striga (Scrophulariaceae) in Africa. Mo. Bot. Gard. Bull. 2001, 88, 60-103. [CrossRef]

18. Mahmoud, B.A.; Hamma, I.L.; Abdullahi, S.; Adamu, Y. Common Striga control methods in Nigeria: A review. Int. J. Agron. Agric. Res. 2013, 3, 26-29.

19. Badu-Apraku, B.; Fakorede, M.A.B.; Menkir, A.; Kamara, A.Y.; Adam, A. Effect of drought screening methodology on genetic variances and covariances in Pool 16 DT maize population. J. Agric. Sci. 2004, 142, 445-452. [CrossRef]

20. Yoder, J.; Scholes, J. Host plant resistance to parasitic weeds; recent progress and bottlenecks. Curr. Opin. Plant Biol. 2010, 13, 478-484. [CrossRef] [PubMed]

21. Ransom, J.K.; Eplee, R.E.; Langston, M.A. Genetic variation for resistance to Striga in maize. Cereal Res. Commun. 1990, 18, 392-399. 
22. Oswald, A.; Ransom, J.K. Response of maize varieties to Striga infestation. Crop Prot. 2004, 23, 89-94. [CrossRef]

23. Fisher, M.; Abate, T.; Lunduka, R.W.; Asnake, W.; Alemayehu, Y.; Madulu, R.B. Drought tolerant maize for farmer adaptation to drought in sub-Saharan Africa: Determinants of adoption in eastern and southern Africa. Clim. Chang. 2015, 133, 283-299. [CrossRef]

24. CIMMYT. The Drought Tolerant Maize for Africa Project. DTMA Brief. September 2013. Available online: http://dtma.cimmyt org/index.php/about/background (accessed on 2 March 2019).

25. Betrán, F.J.; Beck, D.; Bänziger, M.; Edmeades, G.O. Genetic analysis of inbred and hybrid grain yield under stress and non-stress environments in tropical maize. Crop Sci. 2003, 43, 807-817. [CrossRef]

26. Bänziger, G.O.M.; Mickelson, H.R.; Peña-Valdivia, C.B. Developing Drought and Low N Tolerant Maize, Proceedings of a Symposium, 25-29 March 1996; CIMMYT: El Batán, Mexico, 1997.

27. Cairns, J.E.; Hellin, J.; Sonder, K.; Araus, J.L.; MacRobert, J.F.; Thierfelder, C.; Prasanna, B.M. Adapting maize production to climate change in sub-Saharan Africa. Food Sec. 2013, 5, 345-360. [CrossRef]

28. Statistics, Research and Information Directorate (SRID) of the Ministry of Food and Agriculture (MoFA), 2015 Agriculture in Ghana: Facts and Figures. 2016. Available online: https: / $/$ www.google.com.gh/url? sa=t\&rct=j\&q=\&esrc=s\&source=web\&cd= 10\&ved=0ahUKEwje_r2dmOzZAhWpFZoKHX_CA6oQFghoMAk\&url=http $\% 3$ A \%2F\%2Fwww.agrofood-westafrica.com $\%$ 2Ffileadmin\%2Fuser_upload\%2Fmessen\%2Fagrofood-Westafrica\%2FBrochure\%2FAGRICULTURE-IN-GHANA-Facts-andFigures-2015.pdf\&usg=AOvVaw3s6PaIMareDuDYoEbLYjn8 (accessed on 15 April 2020).

29. Badu-Apraku, B.; Abamu, F.J.; Menkir, A.; Fakorede, M.A.B.; Obeng-Antwi, K.; The, C. Genotype by environment interactions in the regional early variety trials in West and Central Africa. Maydica 2003, 48, 93-104.

30. Cechin, I.; Press, M.C. Influence of nitrogen on growth and photosynthesis of a $\mathrm{C}_{3}$ cereal, Oryza sativa, infected with the root hemiparasite Striga hermonthica. J. Exp. Bot. 1994, 45, 925-930. [CrossRef]

31. Kim, S.K.; Adetimirin, V.O. Responses of tolerant and susceptible maize varieties to timing and rate of nitrogen under Striga hermonthica infestation. Agron. J. 1997, 89, 38-44. [CrossRef]

32. Kostandini, G.; La Rovere, R.; Abdoulaye, T. Potential impacts of increasing average yields and reducing maize yield variability in Africa. Food Policy 2013, 43, 213-226. [CrossRef]

33. Edmeades, G.O.; Banziger, M.; Cortes, C.; Ortega, A.C. From stress-tolerant populations to hybrids: The role of source germplasm. In Developing Drought and Low-N Tolerant Maize; Edmeades, G.O., Banziger, M., Mickelson, H.R., Pena-Valdivia, C.B., Eds.; CIMMYT: El Batan, Mexico, 1997; pp. 263-273.

34. Manyong, V.M.; Kling, J.G.; Makinde, K.O.; Ajala, S.O.; Menkir, A. Impact of IITA-Improved Germplasm on Maize Production in West and Central Africa; IITA: Ibadan, Nigeria, 2000; pp. 6-8.

35. Bänziger, M.; Edmeades, G.O.; Beck, D.; Bellon, M. Breeding for Drought and Nitrogen Stress Tolerance in Maize: From Theory to Practice; CIMMYT: El Batan, Mexico, 2000.

36. Banziger, M.; Lafitte, H.R. Maize population improvement for low soil N: Selection gains and identification of secondary traits. In Developing Drought- and Low N-Tolerant Maize, Proceedings of a Symposium, 25-29 March 1996; Edmeades, G.O., Ed.; CIMMYT: El Batán, Mexico, 1997; pp. 485-489.

37. Presterl, T.; Groh, S.; Landbeck, M.; Seitz, G.; Schmidt, W.; Geiger, H.H. Nitrogen uptake and utilization efficiency of European maize hybrids developed under conditions of low and high nitrogen input. Plant Breed. 2002, 121, 480-486. [CrossRef]

38. Gallais, A.; Coque, M. Genetic variation and selection for nitrogen use efficiency in maize: A synthesis. Maydica 2005, 50, 531-537.

39. Akinwale, R.O.; Badu-Apraku, B.; Fakorede, M.A.B. Evaluation of Striga-resistant early maize hybrids and test locations under Striga-infested and Striga-free environments. Afr. Crop Sci. J. 2013, 21, 1-19.

40. Comstock, R.E.; Moll, R.H. Genotype- environment Interactions. In Statistical Genetics and Plant Breeding. NAS-NRC 1963, 982, 164-196.

41. Edmeades, G.O.; Bolanos, J.; Bänziger, M.; Ribaut, J.M.; White, J.W.; Reynolds, M.P.; Lafitte, H.R. Improving crop yields under water deficits in the tropics. In Crop Productivity and Sustainability-Shaping the Future, Proceedings of the 2nd International Crop Science Congress, 2; New Delhi (India), 17-24 November 1996; Chopra, V.L., Singh, R.B., Varma, A., Eds.; IBH: Oxford, UK, 1998; pp. 437-451.

42. Bänziger, M.; Edmeades, G.O.; Lafitte, H.R. Selection for drought tolerance increases maize yields across a range of nitrogen levels. Crop Sci. 1999, 39, 1035-1040. [CrossRef]

43. Menkir, A.; Akintunde, A.O. Evaluation of the performance of maize hybrids, improved open-pollinated and farmers' local varieties under well-watered and drought stress conditions. Maydica 2001, 46, 227-238.

44. Badu-Apraku, B.; Fakorede, M.A.B.; Oyekunle, M.; Akinwale, R.O. Selection of extra-early maize inbreds under low N and drought at flowering and grain-filling for hybrid production. Maydica 2011, 56, 1721.

45. Menkir, A.; Kling, J.G. Response to recurrent selection for resistance to Striga hermonthica (Del.) Benth in a tropical maize population. Crop Sci. 2007, 47, 674-684. [CrossRef]

46. Monneveux, P.; Sanchez, C.; Beck, D.; Edmeades, G.O. Drought tolerance improvement in tropical maize source populations: Evidence of progress. Crop Sci. 2006, 46, 180-19126. [CrossRef]

47. Badu-Apraku, B.; Oyekunle, M. Genetic analysis of grain yield and other traits of extra-early yellow maize inbreds and hybrid performance under contrasting environments. Field Crop. Res. 2012, 129, 99-110. [CrossRef] 
48. Badu-Apraku, B.; Fakorede, M.A.B.; Lum, A.F. Evaluation of experimental varieties from recurrent selection for Striga resistance in two extra-early maize populations in the savannas of West and Central Africa. Exp. Agric. 2007, 43, 183-200. [CrossRef]

49. Kim, S.K. Genetics of maize tolerance of Striga hermonthica. Crop Sci. 1994, 34, 900-907. [CrossRef]

50. Bremner, J.M.; Mulvaney, C.S. Nitrogen-Total. In Methods of Soil Analysis, 2nd ed.; Page, A.L., Miller, R.H., Keeny, D.R., Eds.; Agronomy, 9; ASA and SSSA: Madison, WI, USA, 1982; pp. 595-624.

51. Abe, A.; Adetimirin, V.O.; Menkir, A.; Moose, S.P.; Olaniyan, A.B. Performance of tropical maize hybrids under conditions of low and optimum levels of nitrogen fertilizer application, grain yield, biomass production and nitrogen accumulation. Maydica 2013, $58,141-150$.

52. SAS Institute Inc. Base SAS 9.2 Procedures Guide; SAS Institute Inc.: Cary, NC, USA, 2008.

53. MIP Maize Improvement Program, Archival Report, 1988-1992_Part I. Maize population improvement. In Ibadan: Crop Improvement Division; IITA: Ibadan, Nigeria, 1996.

54. Akintunde, A.N. Path Analysis Step by Step Using Excel. J. Tech. Sci. Technol. 2012, 1, 9-15.

55. Yan, W. GGE biplot: A windows application for graphical analysis of multi-environment trial data and other types of two-way data. Agron. J. 2001, 93, 1111-1118. [CrossRef]

56. Yan, W.; Rajcan, I. Biplot evaluation of test sites and trait relations of soybean in Ontario. Crop Sci. 2002, 42, 11-20. [CrossRef] [PubMed]

57. Yan, W.; Tinker, N.A. An integrated biplot analysis system for displaying, interpreting, and exploring genotype by environment interactions. Crop Sci. 2005, 45, 1004-1016. [CrossRef]

58. Yan, W.; Kang, M.S.; Ma, B.; Woods, S.; Cornelius, P.L. GGE Biplot vs. AMMI analysis of genotype-by-environment data. Crop Sci. 2007, 47, 643-655. [CrossRef]

59. Badu-Apraku, B.; Menkir, A.; Fakorede, M.A.B.; Ajala, S.; Ellis-Jones, J. Building Partnerships and Encouraging Innovation for Sustainable Maize Production: The West and Central Africa Collaborative Maize Research Network, Achievements And Impact; IITA: Ibadan, Nigeria, 2012; p. 82.

60. Badu-Apraku, B.; Oyekunle, M.; Fakorede, M.A.B.; Vroh, I.; Akinwale, R.O.; Aderounmu, M. Combining ability, heterotic patterns and genetic diversity of extra-early yellow inbreds under contrasting environments. Euphytica 2013, 192, 413-433. [CrossRef]

61. Akaogu, I.C.; Badu-Apraku, B.; Adetimirin, V.O.; Vroh-Bi, I.; Oyekunle, M.; Akinwale, R.O. Genetic diversity assessment of extra-early maturing yellow maize inbreds and hybrid performance in Striga-infested and Striga-free environments. J. Agric. Sci. 2013, 151, 519-537. [CrossRef]

62. Meseka, S.K.; Menkir, A.; Ibrahim, A.E.S.; Ajala, S.O. Genetic analysis of performance of maize inbred lines selected for tolerance to drought under low nitrogen. Maydica 2006, 51, 487-495.

63. Makumbi, D.; Betran, F.J.; Banziger, M.; Ribaut, J. Combining ability, heterosis and genetic diversity in tropical maize (Zea mays L.) under stress and non-stress conditions. Euphytica 2011, 180, 143-162. [CrossRef]

64. Menkir, A.; Adetimirin, V.O.; Yallou, C.G.; Gedil, M. Relationship of genetic diversity of inbred lines with different reactions to Striga hermonthica (Del.) Benth and the performance of their crosses. Crop Sci. 2010, 50, 602-611. [CrossRef]

65. Edmeades, G.O.; Bolanos, J.; Hernandez, M.; Bello, S. Causes for silk delay in lowland tropical maize. Crop Sci. 1993, 33, 1029-1035. [CrossRef]

66. Elings, A.; White, J.; Edmeades, G.O. Modelling the consequences of water limitations at flowering and nitrogen shortage in tropical maize germplasm. In Developing Drought and Low N-Tolerant Maize. Proceedings of a Symposium, 25-29 March 1996; Edmeades, G.O., Bänziger, M., Mickelson, H.R., Peña-Valdivia, C.B., Eds.; CIMMYT: El Batan, Mexico, 1997.

67. Chun, L.; Mi, G.; Li, J. Genetic Analysis of Maize Root Characteristics in Response to Low Nitrogen Stress. Plant Soil 2005, 276, 369. [CrossRef]

68. Adetimirin, O.; Aken'ova, V.E.; Kim, M.K. Effects of Striga hermonthica on yield components in maize. J. Agric. Sci. 2000, 135, 185-191. [CrossRef]

69. Badu-Apraku, B.; Akinwale, R.O.; Fakorede, M.A.B. Selection of early maturing maize inbred lines for hybrid production using multiple traits under Striga-infested and striga-free environments. Maydica 2010, 55, 261-274.

70. Lane, J.A.; Child, D.V.; Moore, T.H.M.; Arnold, G.M.; Bailey, J.A. Phenotypic characterization of resistance in Zea diploperennis to Striga. Maydica 1997, 42, 45-51.

71. Lafitte, H.; Edmeades, G. Improvement for tolerance to low soil nitrogen in tropical maize I. Selection criteria. Field Crop. Res. 1994, 39, 1-14. [CrossRef]

72. Sharifi, R.S.; Namvar, A. Effects of time and rate of nitrogen application on phenology and some agronomical traits of maize (Zea mays L.). Biologija 2016, 62, 35-45. [CrossRef]

73. Adu, G.B.; Akromah, R.; Abdulai, M.S.; Obeng-Antwi, K.; Alidu, H.; Tengan, K.M.L. Trait association for improved grain yield of extra-early maturing maize hybrids evaluated in the Forest and Transitional zones of Ghana. Aust. J. Crop Sci. 2016, 10, 1127-1135. [CrossRef]

74. Sangoi, L.; Salvador, R.J. Influence of plant height and of leaf number on maize production at high plant densities. Pesqui. Agropecu. Bras. 1998, 33, 297-306. 